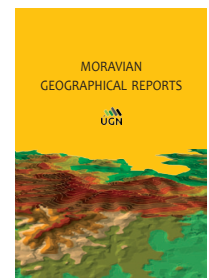

MORAVIAN GEOGRAPHICAL REPORTS

\title{
Industrial clusters in a post-socialist country: The case of the wine industry in Slovakia
}

\author{
Jana NOVOTNÁ a Ladislav NOVOTNÝ a *
}

\begin{abstract}
Research on clusters, unlike cluster initiatives, has not been comprehensively addressed in European postsocialist countries. The aim of this paper is to explore and to analyse quantitatively the spatial organisation of economic activities in the wine industry in Slovakia, and to assess it in terms of the concept of an industrial cluster. The wine industry is considered as a production sector in which location is determined by geographical factors. The research is based on a case study of a wine region located north-east of Bratislava, Slovakia. The primary identification of the cluster potential is based on the assessment of geographic conditions and statistical analyses focused on the spatial concentration of the industry within the defined area. An extensive questionnaire survey provided data for assessing the spatial organisation of economic activities and their impact on regional competitive advantage. Despite the spatial distribution of economic activities and relations among business entities affected by socialist industrialisation and post-socialist transformation, the results show that the industrial cluster was formed in the wine industry and its performance converges with the wine clusters in traditional Western European wine regions.
\end{abstract}

Keywords: industrial cluster, clustering, wine production, post-socialist, Slovakia

Article history: Received 19 November 2018, Accepted 10 May 2019, Published 30 June 2019

\section{Introduction}

Industrial clusters, as popularised by Porter (1990, 1998a, 1998b), have been addressed in many studies since the early 1990s, making them a subject of research at the conjunctions of the economic and geographical sciences. As a model of the spatial organisation of particular industries, clustering gained the image of a universal tool for regional development (cf. Drewello, Helfer and Bouzar, 2016), as well as in spatial planning and national politics.

The concept originates from the environment of the Western market economy, where it was also the most frequently and most thoroughly researched topic (cf. Lindqvist, Ketels and Sölvell, 2013; Porter, 1990). Less attention has been paid to this concept in the post-socialist Central and Eastern European countries (CEECs). The reason for that could be the implementation of socialist industrialisation and centrally-planned economies by these countries after the Second World War. The organisation and location of economic activities in such conditions often resulted from political decisions, regardless of geographical localisation potential, local competitive advantages or the economic history of a region. Socialist industrialisation policies preferred huge industrial estates at the expense of small business entities, that in turn considerably limited competition and cooperation (cf. Kulla, 2010). Several levels of territorial industrial units were delimited in Slovakia (Mládek, 1990) by the end of the socialist era, reflecting the spatial distribution of industrial production under the state rules.

Despite its different conceptual and methodological approach compared to Porter's concept of an industrial cluster, the thoroughly elaborated delimitation of industrial spatial organisation by Mládek (1990) can be considered an alternative to clusters in a broader sense. During the post-socialist transformation, the economic downturn was followed by a huge amount of foreign direct investments. Such actions contributed to considerable changes in the spatial distribution of economic activities (cf. Kulla, 2010). The regionalisation of industrial activities by Mládek (1990), however, was not followed by any similar and comprehensive research.

Geographical location in specific environments is one of the key features of industrial clusters (Porter, 1990) and certain industries are very strongly dependent on geographic conditions. Therefore, it is possible to assume that some naturally-developed industrial clusters exist even in CEECs. A certain potential for cluster formation

\footnotetext{
a Institute of Geography, Faculty of Science, Pavol Jozef Šafárik University in Košice, Košice, Slovakia

(*corresponding author: L. Novotný, e-mail: ladislav.novotny@upjs.sk)
} 
(further referred to as cluster potential) was identified in the CEECs by Brodzicki et al. (2002), Dziemianowicz and Olejniczak (2002), Ketels and Sölvell (2006), and Szultka and Wojnicka (2003), particularly in modern industries such as information-communication technologies (ITC) or creative industries.

The identified research gap opens space for further scientific exploration, which we aim to fill in this paper. The objective is to explore and analyse quantitatively the spatial organisation of economic activities in the wine industry in Slovakia, and to assess it in terms of the industrial cluster concept. The wine industry is considered as a production sector in which spatial embeddedness is substantially determined by geographical conditions. Hence, we anticipate that its spatial organisation is less distorted by socialist industrialisation and post-socialist transformation than other industries. This research project is based on a case study of the territory comprised by the wine route association of Malokarpatská vínna cesta (MVC) (see Fig. 1). The study area will be further referred to as the MVC region. It is the core part of the wine-producing area of Malokarpatská vinohradnícka oblast', in the foothills area of the Malé Karpaty Mountains north-east of Bratislava, Slovakia. The hypothesis is that due to specific geographical conditions, the wine industry formed an industrial cluster in the MVC region despite being influenced by socialist central planning and post-socialist transformation. The wine route association is perceived as a cluster initiative that could contribute to the emergence of a natural wine cluster. The study employs publically available statistical data for the identification and delineation of the research area, as well as the results of an extensive questionnaire survey designed for the exploration and assessment of the spatial organisation of economic relations within the area.

The post-socialist transformation in the CEECs happened in the same period when the global wine industry started to change. Traditional wine-producing regions and countries were challenged by the "New World" producers such as Chile, Argentina, California or South Africa (Bortoluzzi et al., 2015; Cusamo, Morrison and Rabellotti, 2010). Various organisations of wine production stimulated research addressing industrial clusters and business networks in traditional Western European countries (e.g. Aiassa et al., 2018; Bortoluzzi et al., 2015; Giuliani, 2007; Morrison and Rabellotti, 2009) or in the New World producers (e.g. Giuliani; 2010, 2013; Ruffoni et al., 2013). Comparative studies of both kinds of regions also originated (e.g. Cusmano, Morrison and Rabellotti, 2010; Zen, Fensterseifer and Prévot, 2011). The CEECs were omitted in such research, however. Hence, the contribution of this paper is towards a more comprehensive understanding of the development of wine clusters and their performance in various historical, economic and geopolitical conditions in the globalised wine sector, clearly with an emphasis on CEECs.

\section{Theoretical background}

There is frequent theoretical, terminological and methodological ambiguity in the research of industrial clusters. Researchers tend to adjust their perception of the term cluster to the purposes of their research (see Tab. 1), allowing them to study this issue in various conditions and circumstances on the one hand, but with deteriorating comparability of their research results on the other hand (cf. Brodzicki and Szultka, 2002).

The majority of definitions of (an industrial) cluster is consistent with respect to the existence of relations between actors involved in the cluster and in their geographic proximity. Several authors draw attention to the potential risks associated with excessive orientation to the local economy, to a single sector covered by a cluster, to too strong clustering and business network closure, and/or focus their criticism on the adoption of the cluster concept in policy making (e.g. Marshall, 1890; Martin and Sunley, 2003; Nemcová, 2004; Rosenfeld, 2002). Most scholars (cf. Nemcová, 2004; Bortoluzzi et al., 2015) agree that the formation of a cluster creates an opportunity for the benefit of all involved actors, as well as for a given locality or region. Current research on the development of specific industries in the United States during the Great Recession (2007-2009) confirms the finding that strong industrial clusters improve the growth of regional employment over time, and cluster agglomeration economies lead to resilience during negative economic shocks (Delgado, Porter and Stern, 2016). Evidence from Western Europe indicates that the positive effects of industrial clusters contribute to retain the competitiveness of the involved producers with the producers from the New World (cf. Bortoluzzi et al., 2015; Zen, Fensterseifer and Prévot, 2011).

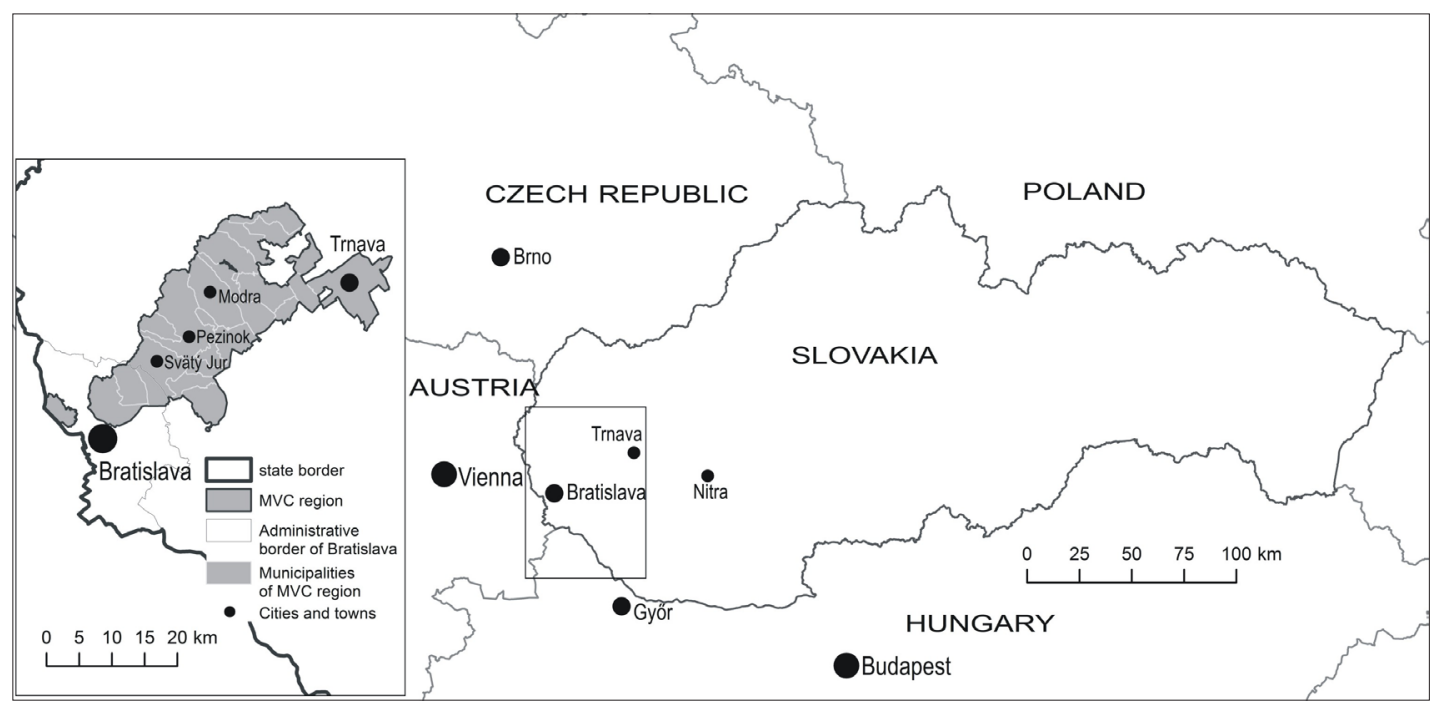

Fig. 1: Location of the study area - the Malokarpatská vínna cesta (MVC) region within Central Europe Source: authors' elaboration 


\begin{tabular}{|c|c|}
\hline Source & Definition \\
\hline Porter (1998a) & $\begin{array}{l}\text { Geographic concentrations of interconnected companies and institutions in a particular field, } \\
\text { encompassing an array of linked industries and other entities important for competition. }\end{array}$ \\
\hline Bergman and Feser (1999) & $\begin{array}{l}\text { A group of business enterprises and non-business organisations for whom membership within } \\
\text { the group is an important element of each member firm's individual competitiveness. }\end{array}$ \\
\hline Skokan (2002a) & $\begin{array}{l}\text { Geographically concentrated industries that gain performance and competitive advantage from } \\
\text { their location and related factors. }\end{array}$ \\
\hline Ketels, Lindqvist and Sölvell (2006) & $\begin{array}{l}\text { Group of companies and other institutions in related industries that are co-located in a specific } \\
\text { geographic region. }\end{array}$ \\
\hline Giuliani (2007) & Geographical agglomeration of firms operating in the same industry. \\
\hline Székely (2008) & $\begin{array}{l}\text { Relatively closed territorial unit that uses a specialised labour market for the migration of wor- } \\
\text { kers among the economic entities of the same or related industry. }\end{array}$ \\
\hline Zen, Fensterseifer and Prévot (2011) & $\begin{array}{l}\text { Grouping of companies and institutions linked to the same industrial sector in a given geogra- } \\
\text { phical area that establish relations of cooperation and competition. }\end{array}$ \\
\hline Delgado, Porter and Stern (2016) & Group of closely related and complementary industries operating within a particular region. \\
\hline
\end{tabular}

Tab. 1: Selected definitions of industrial clusters. Source: authors' compilation from noted sources

Many authors (e.g. Ketels, Lindqvist and Sölvell (2006); Kowalski (2016); Kowalski and Marcinkowski (2012); Lindqvist, Ketels and Sölvell (2013); Sölvell, Lindqvist and Ketels (2003) and others) emphasise the difference between cluster and cluster initiative, although cluster initiative is often referred to as cluster (e.g. Hervas-Oliver, Lleo and Cervello, 2017; Kaźmierski, 2011; Turina et al., 2016), especially in regional development policies. In contrast, clusters have developed independently of political decisions or intervention (Ketels, Lindqvist and Sölvell, 2006; Porter, 2000), while cluster initiatives as defined by Sölvell, Lindqvist and Ketels (2003) are "organised efforts to increase growth and competitiveness of clusters within a region, involving cluster firms, government and/or the research community". Therefore, cluster initiatives (also referred to as constructed clusters) may be considered as top-down formed clusters (cf. Pavelková et al., 2009), while "natural" clusters are generated by market forces and so may be considered as bottom-up formed clusters (cf. Porter, 2000). Such defined cluster initiatives have been formed in the Central and Eastern European post-socialist countries during the later post-socialist transformation period as a tool to support development of specific industries (e.g. Ketels, Lindqvist and Sölvell, 2006; Kowalski, 2016; Marková, 2014; Soviar, 2009). These processes directed scientific attention to cluster initiatives, while natural clusters have been neglected in the research.

Our study perceives the cluster as a phenomenon naturally developed by market forces, as defined by Porter (1990, 1998a: Tab. 1). In this sense, the industrial cluster is characterised by cooperation, but also by the competition of involved entities. This stimulates the efficiency of production and thus increases competitiveness. Industrial clusters tend to develop in those regions providing a competitive advantage to the industry. Thus, the concept of clusters explains why the economy of some regions grows more rapidly than that in other regions.

Appropriate corporate strategy is important but it is not sufficient on its own to achieve competitive advantage for individual business entities (Porter, 1990; 2000). Cluster strength depends on a number of factors enabling success. Porter presented a model of the impact of localisation on competitiveness (see Fig. 2), known as Porter's Diamond, grouping these factors into four interconnected sources of a local competitive advantage.

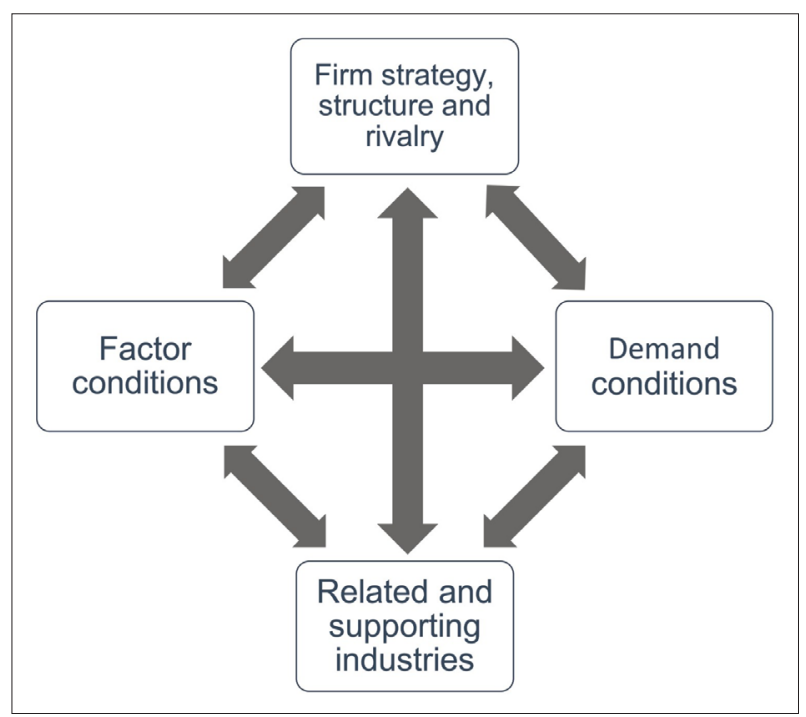

Fig. 2: Determinants of national competitive advantage known as the Porter's Diamond

Source: Porter (1990), authors' sketch

The factor conditions represent factors of production such as skilled labour, infrastructure, natural resources, energy and/or capital necessary to make the area competitive in a given industry. Demand conditions refer to the nature of the home market (Porter, 1990). A sophisticated and demanding home market can also be a spur to innovations and improvement in the industry (cf. Riddle, 2016). Related and supporting industries refer to the presence of supplier industries and other related industries (Porter, 1990). Firm strategies, structure and rivalry also affect the achievement of competitive advantage, but Porter also notes that national features like education, culture and values can shape these factors (cf. Riddle, 2016). Porter (1990) introduced these sources of competitive advantage for the national level, but the same process is applicable for the sub-national or regional level (cf. Porter 1998b, 2000).

Stejskal and Hájek (2012) provide a comprehensive review on the approaches to identification and assessment of industrial clusters. This review shows that competitive advantage is the key feature of clusters. Therefore, they propose that analysis of 'competitive advantage' as a method for identifying the industrial cluster. Although 
the method itself is novel, it is based on Porter's Diamond model. Despite many modifications and extensions, and even certain criticisms, Porter's Diamond model has become the basis for the identification and exploration of clusters by many other scholars (e.g. Wilson, 2016). Therefore, Porter's model is also employed in our study as the basic theoretical background for exploring the question of whether the 'potential' turned into the real existence of an industrial cluster in the MVC wine-producing area.

The spatial dimension and the determination of boundaries is a frequently-addressed topic related to industrial clusters. Porter (2000) claims the clusters can range from local (individual cities) through regional and national to international. Moreover, the spatial extent of clusters tends to change over time (Ceccato and Persson, 2002, Porter, 1998b). Such a broadly conceived delimitation of cluster borders resulted in a wave of criticism (e.g. Cortright, 2006; Martin and Sunley, 2003; Simmie, 2004; Székely, 2008), which was often focused on problems with thresholds for the spatial concentration of potential cluster actors (entrepreneurs, companies, and institutions), and their interactions resulting from ambiguous guidelines for border delimitation (cf. Székely, 2008). Most attempts to identify clusters use various levels of higher administrative units (e.g. Ketels and Sölvell, 2006; Popovčić Avrić, Brkić and Šestović, 2016) due to the availability of statistical data. This may be misleading for the spatial extent of industrial clusters, which usually does not respect administrative divisions (cf. Cortright, 2006; Skokan, 2008). This is also the case in the wine industry, where clusters are based on the spatial concentration of vine growing and wine making and/or historically developed ties among local and regional actors. The spatial delimitation of such clusters, in many cases, does not respect the higher level regional administrative or statistical units (e.g. Giuliani, 2007; Morrison and Rabellotti, 2009; Ruffoni et al., 2017).

\section{The wine industry in Slovakia and in the study area}

The origin of wine production in the territory of Slovakia dates back to the era of the Celtic settlements in the $7^{\text {th }}-8^{\text {th }}$ century BC. A rapid development of vine growing and wine making was stimulated by the presence of the Romans in the $1^{\text {st }}-4^{\text {th }}$ century AD (Bad'urík, 2005; Malík, 2005). Vine growing spread almost most of the contemporary Slovakia by the $15^{\text {th }}$ century, but the spatial extent of vineyards started to decrease later (Kazimír, 1986). At the beginning of the $20^{\text {th }}$ century, the vineyards were severely damaged by frost and vine diseases all over Europe, contributing to further shrinkage of their spatial extent in Slovakia (Malík, 2005). This crisis indirectly allowed for the improvement of wine production in some areas, including localities adjacent to Bratislava, as it induced improvements in cultivation and the mechanisation of wine production (Valúšková, 1998).

In the inter-World-War period, the total area of vineyards fell to an historical minimum - less than 10,000 hectares. Thanks to the launching of the large socialist wine factories, the spatial extent of vineyards had more than doubled by the 1960s. But these events, along with collectivisation and the establishment of agricultural cooperatives, led to vine growers' and wine producers' loss of personal relations to the soil, vineyards and wine production (Malík, 2005), which engendered an extremely strong violation of the historical continuities of agriculture and wine making in Slovakia
(Popelková, 2016). The social and economic post-socialist transformation has also had temporal negative impacts. The wine producers had to deal with international competition in the market economy and the vine growers lost their state subsidies, and subsequently competitiveness in the international market (cf. Valúšková, 1998). After 1989, restitutions brought property and land back to the original owners and their heirs (Valúšková, 1998). Many of them had lost relationships with the industry, however, or they lacked the appropriate skills and knowledge. Unsettled ownerships complicated any development in the wine industry, even long after the restitutions (Hronský and Pintér, 2009). Addressing the development of the wine industry in the Czech Republic, Grabavčicová (2016, p. 26) emphasises the fact that post-socialist transformations also brought the need to re-establish economic relations between the vine growers on the one hand and wine makers on the other hand, under capitalist conditions.

Moreover, the post-socialist transformation years coincided with the period when the global wine industry became mature, and because of the rapid growth of the "New World" producers, global wine production exceeded global demand (Bortoluzzi et al., 2015; Thomas, Painbéni and Barton, 2013; Zen, Fensterseifer and Prévot, 2011). This created strong competitive pressures on production in traditional (European) wine regions, and made the transformation process in Slovakia even more difficult. A further decrease in the acreage of vineyards was recorded with the accession of Slovakia to the European Union, due to the adoption of the EU Common Agricultural Policy (Rovný, Dobák and Nagyová, 2010). The effect was only temporary, however, and the adoption of support measures later led to stabilisation in the spatial extent of vineyards, and even to a certain revival of the wine industry in Slovakia (Haluza, 2018).

A basic structure for the current regionalisation of viticulture in Slovakia was legally adopted in 1996. Since 2009 there have been six wine-producing areas (see Fig. 3), consisting of 40 districts involving a total of 503 municipalities (NCSR, 2009). In April 2018, another 199 municipalities were granted the status of wine municipalities, hence increasing their total number to 702 with the number of wine-producing areas and districts unchanged (CCTIA, 2018).

The Malokarpatská vinohradnícka oblast' (MVC) wineproducing area is the largest in Slovakia with respect to the acreage of vineyards. The area is spatially fragmented, however, and also heterogeneous when considering geographical conditions. Therefore, we focused on a smaller area with the largest concentration of wine firms, which is a prerequisite for the existence of strong personal and business networks. Based on the identification of cluster potential (see Section 5.1), the spatial extent of this research project was limited to the wine municipalities of the MVC region, with a relatively high degree of geographical and historical homogeneity, and under the assumption of the existence of inter-entity linkages encouraged by the 'Malokarpatská vínna cesta' (wine route association) operating in the MVC region. This is similar to the approach used by Morrison and Rabellotti (2009), who researched an Italian wine cluster historically developed in the Colline Novaresi wine route in the Piedmont region. Identifying the core areas of wine-producing regions with a wine cluster is common in research endeavours, in traditional as well as in New World wine-producing countries (e.g. Giuliani, 2007; Morrison and Rabellotti, 2009; Ruffoni et al., 2017). 


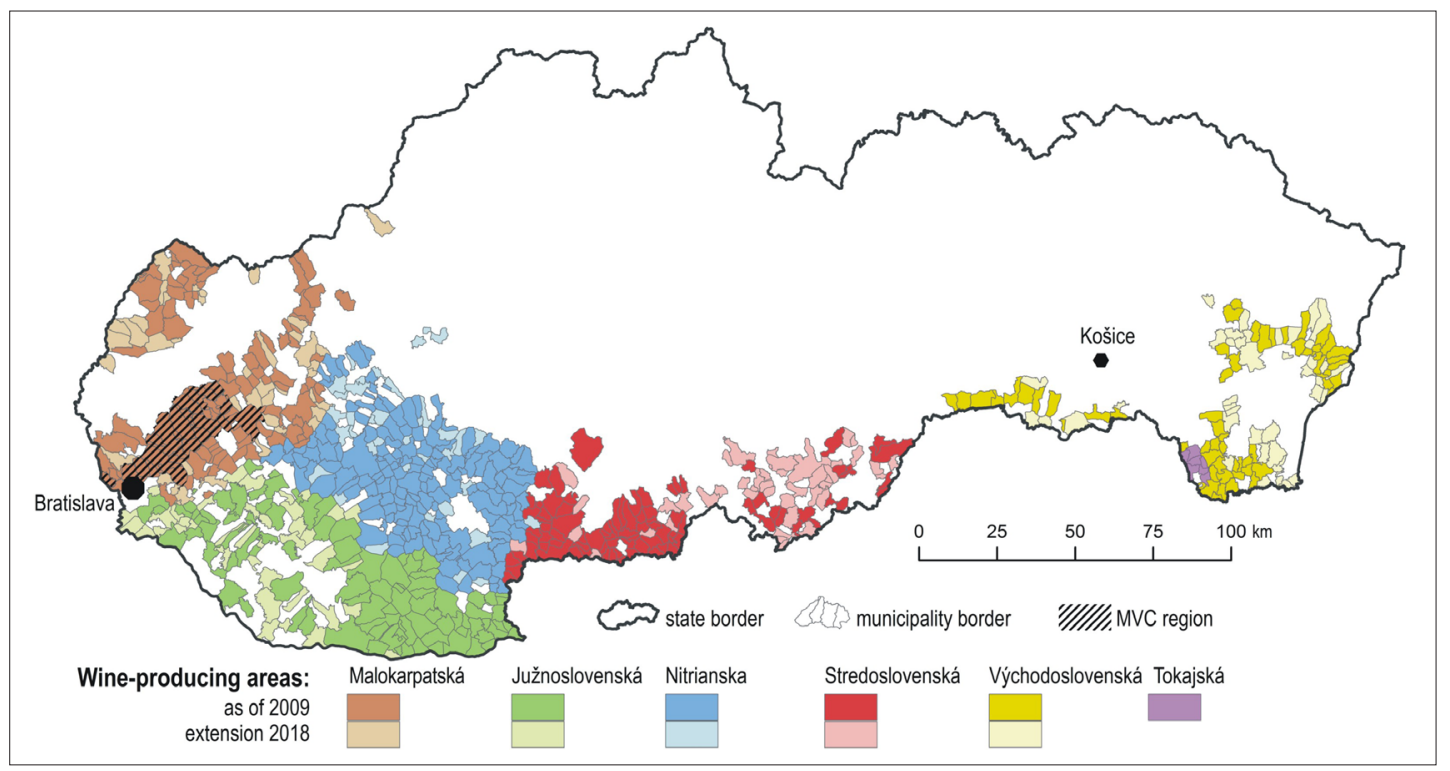

Fig. 3: Wine-producing areas in Slovakia

Source of data: CCTIA (2018), NCSR (2009); authors' elaboration

The total area of the MVC region is $652 \mathrm{~km}^{2}$. It is located on the south-eastern slopes of the Male Karpaty mountain range (the south-westernmost part of the Carpathians), interfacing the Danubian Lowland as a part of the Pannonian Plain. It consists of 27 municipalities, including four Bratislava city-boroughs (in the south-west) and the city of Trnava in the east. Therefore, the MVC region benefits from a location between the capital city and one of the major regional and economic centres in Slovakia in terms of economy and infrastructure. The wine industry has considerably influenced identity in the territory (Máryássyová and Gurňák, 2016) and it has been the subject of recent geographical research (e.g. Karlík et al., 2017; Hanušin and Otahel', 2013; Hanušin and Štefunková, 2015) related to the wine industry.

\section{Methods and data}

The attention paid to clusters has resulted in a huge and diverse range of methods proposed for the identification of cluster potential and the cluster itself. Bergman and Feser (1999), Stejskal (2011) and Stejskal and Hájek (2012) provide comprehensive reviews of the methods.

Bergman and Feser (1999) and Stejskal and Hájek (2009) proposed a classification of the methods by the spatial level of the research. They conclude that the role of quantitative methods declines in favour of qualitative methods in the direction from macro-level (huge international clusters) to micro-level (one city cluster or clusters covering a limited number of cases (e.g. municipalities).

Cortright (2006), Pavelková et al. (2009) and Stejskal and Hájek (2012) identified two basic research approaches: (1) the "top-down" approach based on quantitative methods and statistical analyses, as these methods help to reveal industries and regions with cluster potential; and (2) the "bottom-up" approach focused on the exploration of relations and links among actors in a given region and industry. The latter is based on qualitative methods and data obtained by questionnaires and surveys, and so it helps to assess the exploitation of the cluster potential.

A combination of both approaches is the most appropriate way to obtain comprehensive knowledge about the industrial cluster (cf. Bergman and Feser, 1999; Cortright, 2006; Hofe and Chen, 2006; Pavelková et al., 2009; Stejskal and Hájek, 2012; Székely, 2008) and so it is employed by this study. Table 2 summarises an overview of the most frequently applied quantitative methods for the cluster potential identification.

The localisation quotient (LQ) is most frequently used for cluster potential identification (cf. Stejskal and Hájek, 2012). This is mainly due to the lack of sufficient and reliable data for the application of the other indicators, as is the case for statistical data in Slovakia (Székely, 2008). The

\begin{tabular}{ll}
\hline Method & \multicolumn{1}{c}{ Sources } \\
\hline Localisation (location) quotient & $\begin{array}{l}\text { Akundi (2003), Griffith and Paelinck (2018), Oort et al. (2008), Öztürk (2009), Pavelková et al. } \\
(2009), \text { Sambidi (2008), Skokan (2002b), Szymańska and Sroda-Murawska (2013), Žižka (2010) }\end{array}$ \\
Shift-share analysis & Aihu and Guihua (2013), Akundi (2003), Sambidi (2008), Žižka (2010) \\
Input-output analysis & Bergman and Feser (1999), Duque and Rey (2008) \\
Herfindahl-Hirschman index & Möller and Litzel (2008), Stejskal (2011), Aihu and Guihua (2011) \\
Krugman index & Ezcurra et al. (2006), Marelli (2007), Möller and Litzel (2008) \\
Gini-coefficient & Audtretsch and Feldman (1996), Möller and Litzel (2008) \\
Ellison-Glaeser index & Ellison and Glaeser (1997), Feser (2000), Alecke et al. (2008) \\
\hline
\end{tabular}

Tab. 2: Most popular methods for identification of cluster potential Source: authors' compilation 
localisation quotient is used to evaluate the concentration of activities at a local or regional level against the activity at a higher (national) level (Gregory et al., 2009), which is represented by Slovakia as a whole in this study. The LQ threshold value indicating the concentration of a particular industry in a given region varies among researchers. It is usually 1 or it ranges from 0.85 to 1.2 (Griffith and Paelinck, 2018, p. 62; Potomová and Letková, 2011). The LQ is also applied in our study to assess the existence of a cluster potential in the MVC region.

With the application of $\mathrm{LQ}$, it was necessary to cope with the choice of suitable data, given their limited availability in necessary spatial and sectoral details. To explore the cluster potential, employment is among the most suitable and the most frequently assessed phenomenon (Stejskal and Hájek, 2012). Data from the classification of economic activities issued by the European Commission (NACE) are often used for analyses of the LQ at the level of higher administrative or statistical units. They are not available for the LAU2 (Local administrative Unit), however. Also their reliability is disputable even for the LAU1, because they contain only data for entities with at least 20 employees. Therefore, we applied data on the employment of economically active persons in economic sectors from the most recent (2011) Slovak census (SOSR, 2011), which are available at the LAU2 level and contain all employed persons regardless of the employer size. A weakness of these data is that they show the employment structure of the population according to place of residence and not according to the place of work.

From a sectoral point of view, only data for beverage production generally are available. Considering that there is no major producer of other alcoholic or non-alcoholic beverages in the MVC region, the LQ results are unlikely to be overvalued against the actual concentration of the wine industry. To counter possible distortions, however, we decided in addition to analyse the data on the number of business entities in the wine industry at the LAU2 level, provided by the Statistical Register of Organisations (SOSR, 2012). The entities are recorded according to their official headquarters, which could mean that a subject is located in a certain LAU2 but operates in another LAU2. The overwhelming majority of business entities in the wine industry in Slovakia, however, are small entrepreneurs and family businesses, so we do not expect a statistically significant disproportionate effect between the official address and place of operation.

Although the LQ indicates cluster potential, it does not show interdependence between sectors and business entities, overlooking the character, strength and type of interconnections, such as company cooperation, material or information flows (Blažek and Uhlíř,2011; Pavelková et al., 2009; Skokan, 2002ab). Therefore, we conducted an extensive and detailed questionnaire survey among the wine-producing entities in the area of interest. Despite being time-consuming, this method has been used as the most reliable way to acquire information on inter-entity linkages and relationships in research on industrial clusters in western European and South American wine regions (cf. Bortoluzzi et al., 2015; Giuliani, 2007; Morrison and Rabellotti, 2009; Zen, Fensterseifer and Prévot, 2011). An interview survey was also employed by Grabavčicová (2016) to identify the potential and willingness for wine cluster (cluster initiative) establishment in the South Moravian region of the Czech Republic, but it suffered from the relatively small number of producers who responded.
We aimed the survey at collecting data on the perception of competition and various forms of cooperation, particularly business-to-business relationships. The success of clusters is also strongly associated with the presence of local networks, based on market, social and institutional relationships among the subjects participating in the cluster (Giuliani, 2007). Therefore, the availability of qualified labour and the linking of wine producers to research or educational institutions was also investigated by this survey. The questionnaire consisted of 22 items divided into four groups, reflecting the four sources of competitive advantage of Porter's diamond model (Fig. 2). Prior to the research phase, the questionnaire was piloted with representatives of several wine-producing entities in order to ensure the relevance, clarity and exactness of the questions. The survey was conducted in 2013 in person (in several cases by telephone), allowing the respondents to explain their answers or to express the wider context of the answer. These explanations also contributed to the understanding of local competitive advantage factors.

The respondents were divided into two basic categories business entities (various legal forms) and micro-wine makers. The original purpose was to include only the wine producing business entities. It became evident, however, that micro-winemakers were an integral part of the wine industry business network; therefore we decided to interview also the micro-winemakers. In this paper, the term "microwinemakers" refers to small wine producers who produce wine for their own consumption or for a limited range of consumers, and who are not obliged to be officially registered as a business entity by the authorities.

The aim was to reach as many wine makers as possible in the surveyed area. The database of potential interviewees comprised the 213 members of the MVC association. In addition, other subjects were identified based on the data from the Statistical Register of Organisations (SOSR, 2012), the Trade Register (MISR, 2013), and the Business Register of the Slovak Republic (MJSR, 2013). Only seven more subjects were identified in this way, however, indicating a very high level of involvement in the association.

Although there were 220 potential participants identified, some of them are listed as MVC association members or in other registers, but do not perform any economic activity in the wine industry currently. In total, we carried out 173 interviews. Based on these interviews, 117 (68\%) respondents were categorised as business entities and $56(32 \%)$ as micro-wine makers. Some respondents did not provide any or some responses, however, and they were thus excluded from the statistical evaluation. In total, we completed full interviews with 90 business entities, which indicates a response rate of $77 \%$ in the main category of respondents. In addition, 27 (48\%) microwine makers provided responses to all questions and they were included in the analysis. Regarding the proportion of completed interviews from the total number of identified subjects in the MVC region, the survey was very successful even in comparison with studies from Western European and South American clusters (e.g. Bortoluzzi et al., 2015; Giuliani, 2007; Morrison and Rabellotti, 2009; Zen, Fensterseifer and Prévot, 2011), where the sample of respondents was much smaller.

In this exploratory and descriptive statistical analysis, we evaluated separately the resulting responses for micro-wine makers and business entities by the number of employees, which allowed for capturing differences in performance according to firm size, which tends to affect the intensity 
of involvement in personal and business networks within as well as outside the cluster (cf. Morrison and Rabellotti, 2009). For simplification, we mostly report small business entities (up to 5 employees) and larger business entities (6 and more employees), unless stated otherwise. Small firms and micro-wine makers dominate in the MVC region, making it similar to traditional European regions (cf. Bortoluzzi et al., 2015; Giuliani, 2007; Morrison and Rabellotti, 2009).

\section{Results}

\subsection{Identifying the cluster potential}

The MVC region is located in the most developed part of Slovakia, with a diversified economic structure and the concentration of a considerable part of the employment of the whole country (Cerulíková et al., 2017). This indicates that a number of industries could be concentrated in the region. Nevertheless, based on the data on employment of economically active persons in economic sectors (SOSR, 2011), there are only three sectors with an $\mathrm{LQ}$ value greater than 1.5 in the MVC region. The highest value $(\mathrm{LQ}=1.74)$ was recorded in printing and the reproduction of recording media (NACE - division 18), followed by the manufacture of coke and refined petroleum products $(\mathrm{LQ}=1.56$; NACE division 19). Beverages production (NACE - division 11), which also includes wine production, reached an $L Q=1.52$. The values for other sectors were considerably lower, which means that the beverages production is among the industries with the highest cluster potential in the area. This can be attributed in particular to the production of wine as there is no other major producer of beverages (beers, spirits, soft drinks) in the area.

Based on the 2011 census, the number of workers in the beverages production division in the MVC region was only 421 , constituting $0.43 \%$ of all employed residents. This is quite a small number (comparable with the Coline Novaresi wine cluster in Italy, for example: Morrison and Rabellotti, 2009), in turn indicating the small size of the cluster. Many people who work in the wine industry, however, are not included in the statistics as they can work on a part-time basis and for the census they could indicate the economic division of their main job, and/or many of them could also indicate the sector of agriculture since it also contains vine-growing. Thus, it is possible to estimate that the number of jobs related to vine growing and wine making is higher than that indicated by the statistics. Nevertheless, the proportion of $0.43 \%$ is higher than the similar proportion for whole country $(0.31 \%)$, indicating a certain concentration in the MVC region.

The data on the number of business entities in the wine industry at the level of individual communities make it possible to point to increased spatial concentration of business entities also in locations where employment in the sector under consideration does not reach high $L Q$ values (cf. Szymańska and Środa-Murawska, 2013). To increase the relevance of the results, the LQ values for individual communities (Fig. 4) were supplemented by the spatial distribution of wine-producing business entities (Fig. 5). Both indicators show a significant concentration of the wine sector in the MVC region, thereby also confirming its suitability for research of an industrial cluster.

\subsection{Factor conditions}

Because natural and location factor conditions are themselves prerequisites for the development of the wine industry, this section is focused primarily on labour. In the first step, we investigated if respondents perceive the need for skilled labour. Surprisingly more than 1/3 of them declared that the qualifications of the labour force are not necessary (Fig. 6). The majority of them were micro-wine makers and small business entities. Many of them explained that they do not need "academic qualifications" as their wine making is based on family traditions and experiences. They perceive the latter as sufficient qualifications.

On the other hand, over $60 \%$ of respondents declared the necessity of qualifications. In addition to qualification in viniculture (vine-growing) and enology (wine-making), they expressed a need for qualification in associated fields (marketing and sales). In general, the larger the employer, the greater need for qualified labour and versatility. Subsequently, almost $50 \%$ of respondents agreed that there

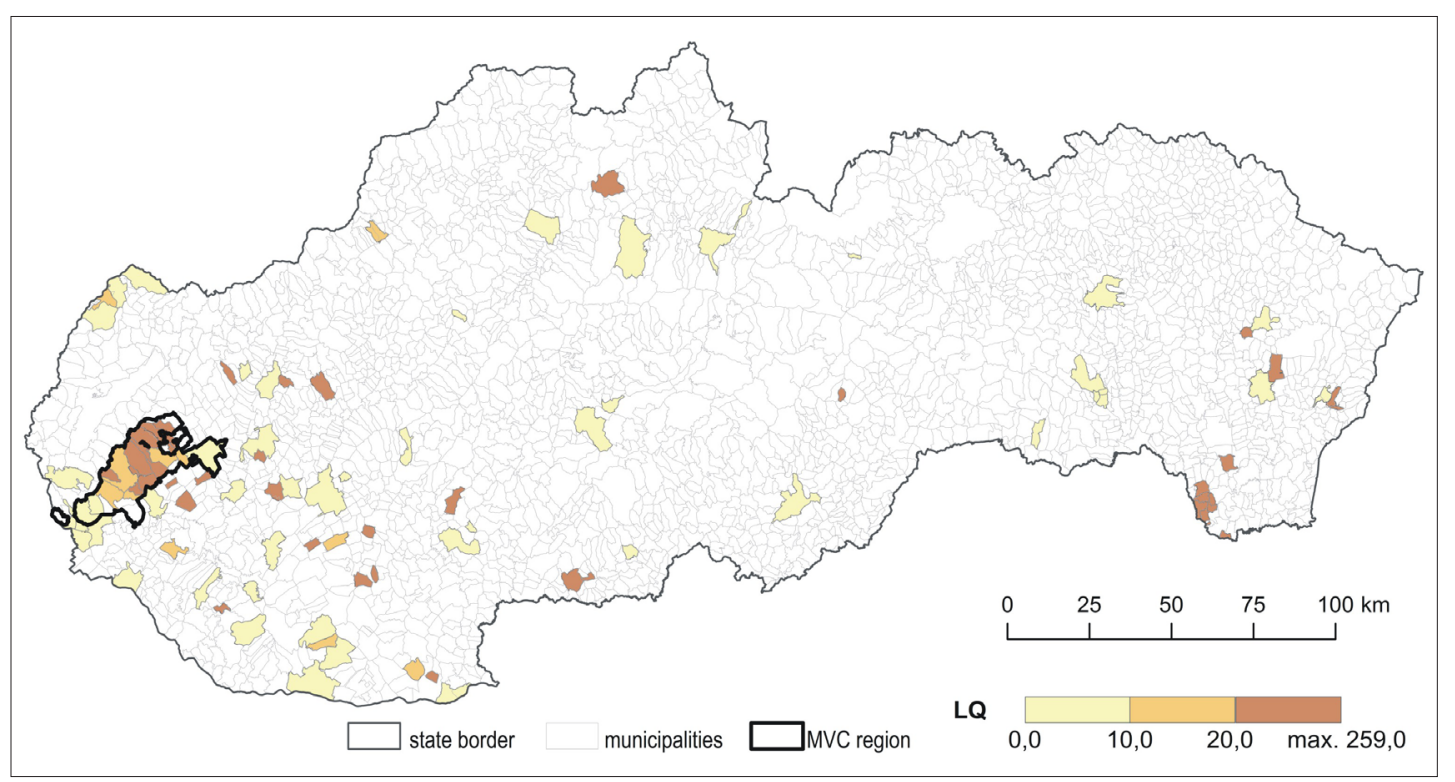

Fig. 4: The spatial distribution of wine-producing business entities indicated by the localisation quotient (LQ) at the level of municipalities

Source of data: SOSR (2012); authors' elaboration 


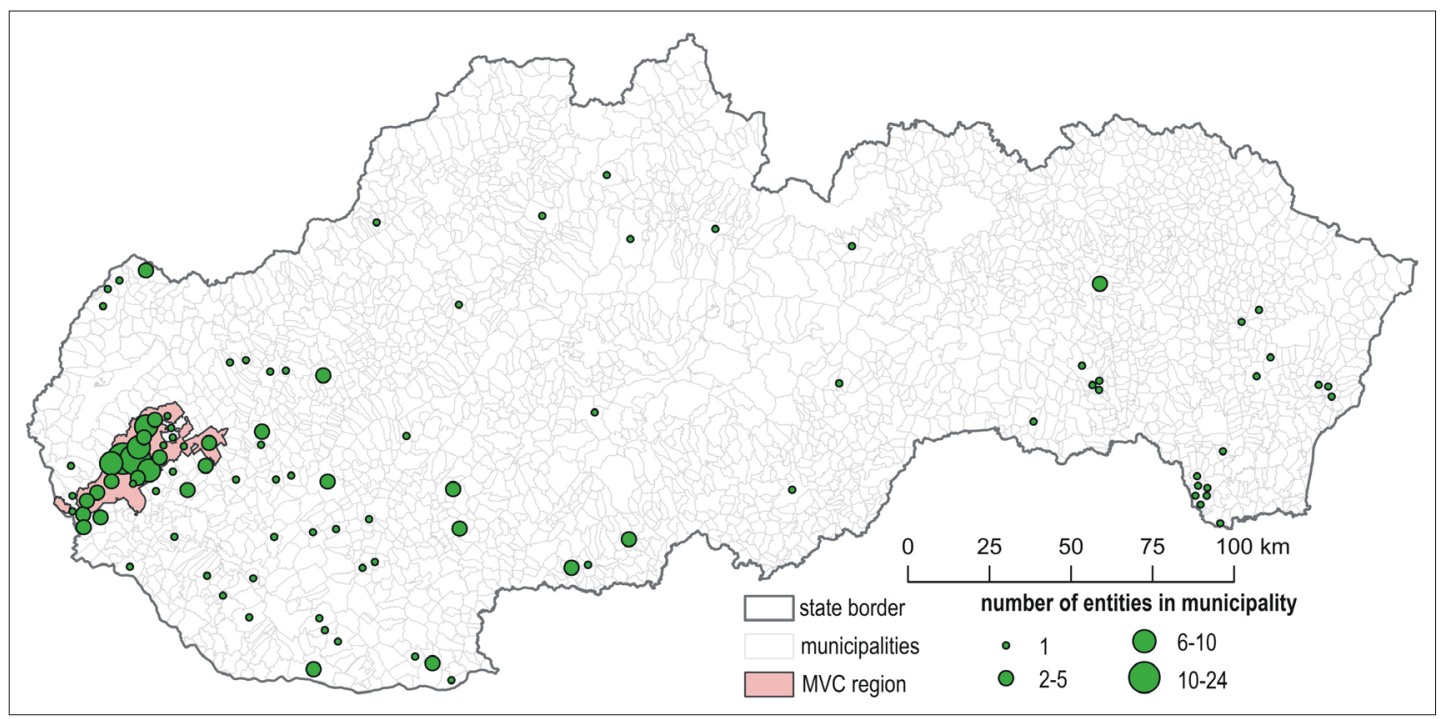

Fig. 5: The spatial distribution of wine business-entities in Slovakia Source of data: SOSR (2012); authors' elaboration

is enough available qualified labour force, but the proportion of positive responses was much lower among larger firms (see Fig. 7), who in a previous question had declared greater need for qualified labour. This question is not applicable to micro-winemakers. As emphasised by one respondent, thanks to the secondary vocational school focused on wine making and fruit production located within the MVC region (in the town of Modra), there are enough people educated in the wine industry, but many graduates perceive work in this sector as unattractive.

The question concerning whether the employees of the surveyed entities had work experience in the wine industry due to previous employment in competing entities was mostly responded to negatively (66.3\%). This may result, however, from a certain share of family companies among the surveyed entities as, in the categories of subjects with six or more employees, the proportion of positive responses was $50 \%$.

Cluster actors tend to address employee training needs together through the organisation of seminars and training activities. Thus, further education of employees reflects

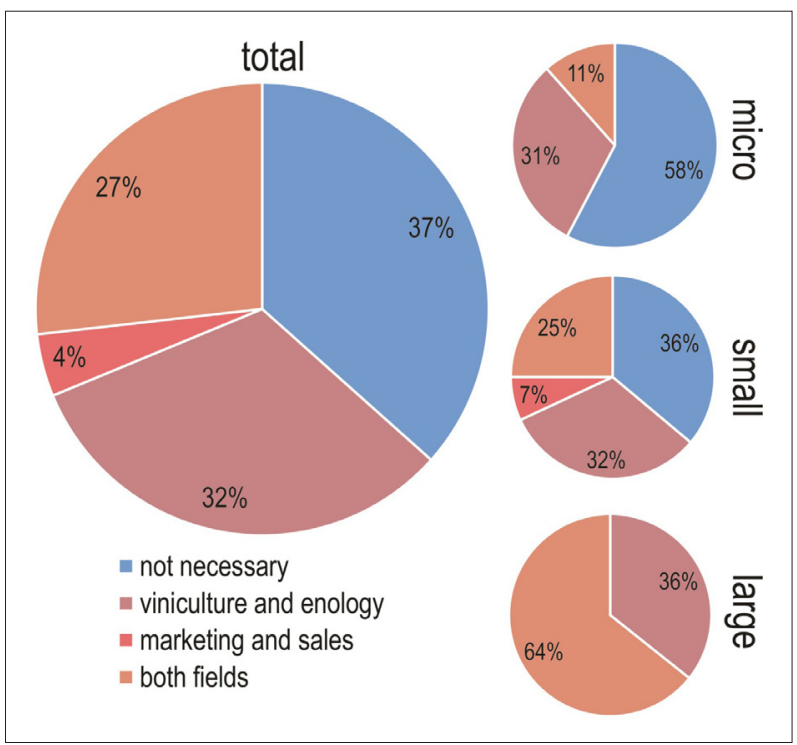

Fig. 6: Requirements on the qualification of employees perceived by winemakers in the MVC region Source: authors' survey specific needs of the businesses (Pavelková et al., 2009). We therefore assumed that if the cluster potential was transformed into a natural cluster, the staff of cluster actors is supposed to take part in educational activities organised either by the MVC association, or some other institution.

Nearly three-quarters of respondents declared that they and/or their staff take part in educational activities. The lowest proportion of positive responses was among microwine makers $(61.5 \%)$, followed by small business entities (72.4\%), while all of the larger business entities were involved in educational activities. Educational activities are mostly organised by other business entities, in particular, supply companies (47.7\%). It shows that in addition to supplier-customer relations, educational relations are also established between wine makers and their suppliers. As much as $40 \%$ of trainings are organised by various associations, with the dominant position of MVC covering almost one-third of all educational activities mentioned by respondents. Some $15.4 \%$ of schoolings are organised by other institutions, particularly secondary schools and universities. One in ten of the manufacturing entities involved in the cluster also provide educational activities. These results indicate the existence of the cluster, which is confirmed by the spatial distribution of educational

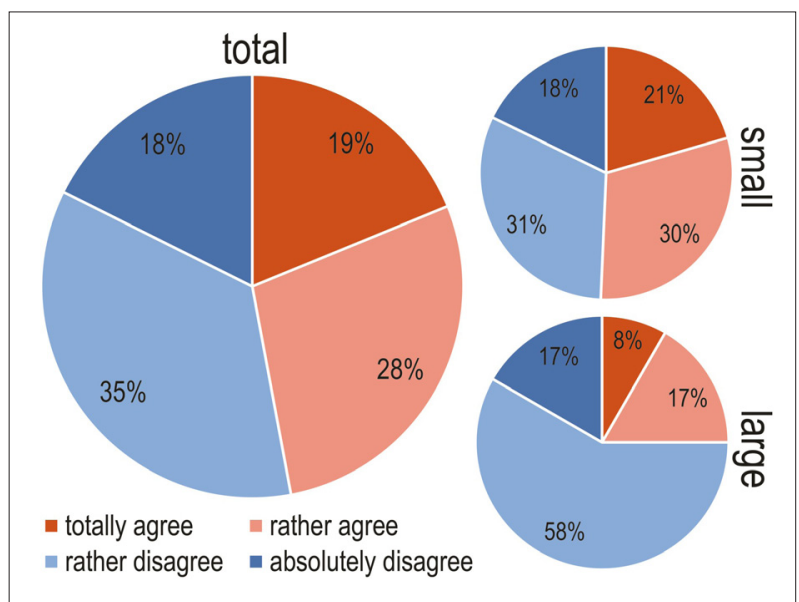

Fig. 7: Responses to the statement: There is a sufficient amount of qualified labour in the regional labour market Source: authors' survey 
activities providers mentioned in the survey. Out of 25 providers, 16 are located directly in the MVC region. Another six providers are located in Bratislava but beyond the border of the MVC region.

Although very important, educational activities are only one of several ways that the survey respondents obtained new knowledge and information. Among other sources labelled as very or more important are professional journals and books $(90.4 \%)$, followed by feedback from customers (87.3\%), informal meetings with managers and experts from other businesses $(81.4 \%)$, wine routes, expositions and open cellars days $(75.0 \%)$, and other sources.

These findings show that common activities within the MVC association, as well as formal or informal cooperation among business entities, play important roles in knowledge improvement and information distribution among the actors in a potential cluster. Together with previous findings, it indicates that the state of factor conditions corresponds to the existence of a natural industrial cluster in the MVC region.

\subsection{Demand conditions}

In this section we focus on the innovativeness of the potential cluster actors and its causes, including the role of market demand and the demands of local customers. We also assessed customers and the forms of distribution of production outputs.

More than nine in ten $(92.2 \%)$ of respondents invested in innovations in the decade prior the survey (2004-2013). All of those who did not invest were small businesses with up to 5 employees. All larger employers invested in innovations, as well as $66.7 \%$ of micro-wine makers. In this survey, the respondents could choose from several reasons for introducing innovations, many of which are related to each other. The most often chosen options were: improving the quality of existing products (88.6\% very important, $7.1 \%$ rather important); strong competition in the region $(55.6 \%$ very important, $31.5 \%$ rather important); and the demands of customers (53.1\% very important, $29.7 \%$ rather important). These were followed by introducing new products to the market, reducing costs, and saving time and labour.

Almost one-third (30\%) of the producers sell their product in only one way, mainly by sale in their own cellar, shop or yard sale. In addition to this form of retailing, $42.4 \%$ of respondents distribute the products to the customers by themselves. These entities do not directly establish cooperative links with others for the purpose of sales, but indirectly these kinds of sales are considerably supported by events and marketing activities provided by the MVC and other associations. The remaining $27.6 \%$ of respondents also declared cooperation with third-party subjects, including the customers themselves (see Fig. 8). Among these thirdparty subjects, the most frequently mentioned were two companies (CORNER SK and MonVin), located in Bratislava in the city boroughs which are not included in the MVC region but located in its vicinity, so they can be connected to the nearby cluster and benefit from it.

To assess cluster existence, the spatial pattern of wine distribution is very important. Thus, we focused on the locations of the largest customers. Due to the number of questions on this issue and the high variability in responses, we generalised the results as follows: the majority of wine makers $(84.4 \%)$ distribute their product only within Slovakia. This is largely due to the limited size of Slovak vineyards, and the national market is large enough to sell almost all the product. At a lower geographic level, more than half of the respondents (56.7\%) distribute at least $50 \%$ of their production within the Malokarpatská vinohradnícka oblast' wineproducing area, including $20 \%$ who sell all of their product in this area. Only $4.4 \%$ of respondents sell all of their production within the municipality (LAU2) where they produce it. The rest of the respondents (15.5\%), mainly smaller wine producers, declared exports also to countries outside Slovakia (particularly the Czech Republic and Germany). Surprisingly, the largest proportion of entities exporting abroad is among the small entities of up to 5 employees. These results indicate that the distribution of production from the MVC area is strongly regionally concentrated, but is able to withstand international competition abroad as well.

\subsection{Firm strategy, structure and rivalry}

Rivalry that pushes producers into innovation is among the decisive factors affecting increased competitiveness (Pavelková et al., 2009). A majority of respondents (57\%) agree that competition among wine producers in the MVC region is strong (see Fig. 9), and almost the same proportion perceive the high number of competitors. On the other hand, they do not see distance between producers as a major source of competition. There are no considerable differences among categories of respondents by size, so the perception of the intensity of competition is roughly equal.

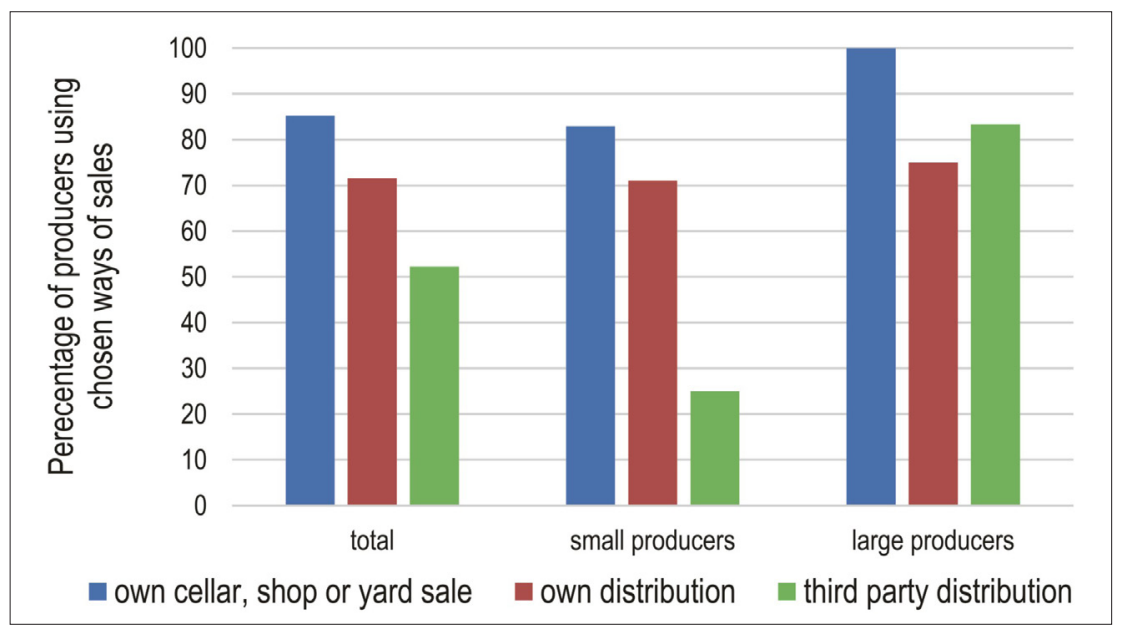

Fig. 8: Means of wine sales in the MVC region, depending on the size of the producer Source: authors' survey 


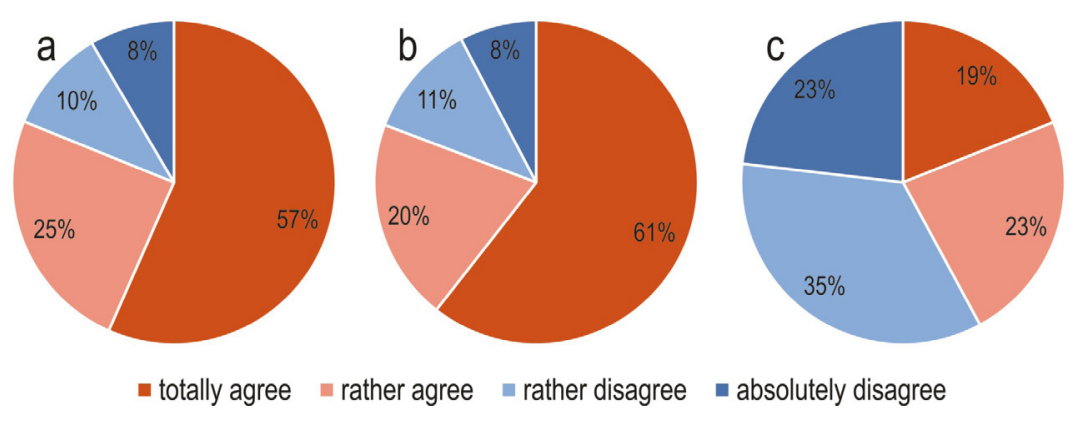

Fig. 9: Responses of participants to the statement: a) The competition among wine producers in the MVC region is strong; $b$ ) The number of competitors is high in the MVC region; c) The intensity of competition decreases with the increasing distance between competitors. Source: authors' survey

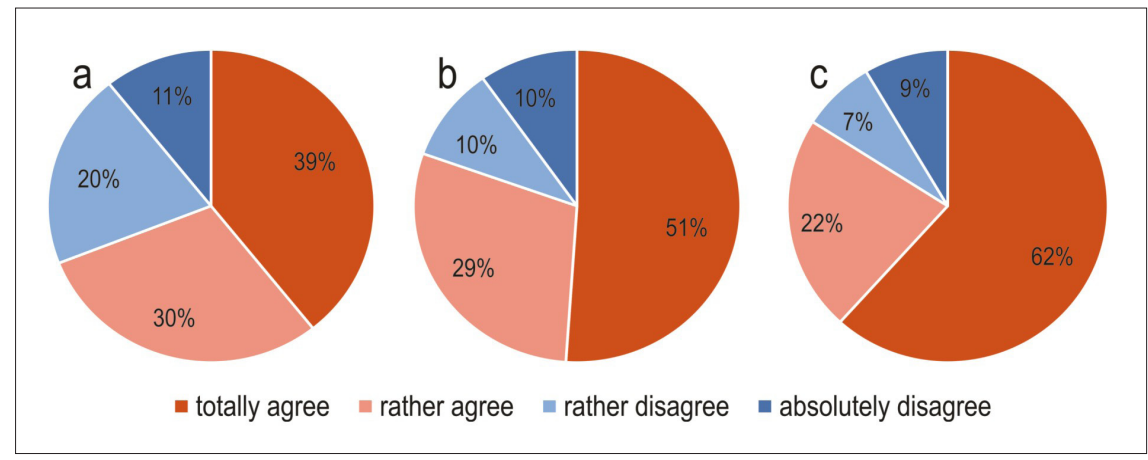

Fig. 10: Main forms of competition declared by respondents: a) Introducing new wines to the market; b) Price; c) Quality of wines. Source: authors' survey

The rivalry between wine producers is stimulated mainly by a combination of non-price (wine quality) and price competition (Fig. 10). In this context, several producers criticised the forms of competition that they consider to be often beyond wine making ethics (i.e. price dumping). Introducing new products to the market also plays a considerable role in competition. Among other non-price forms are the introduction of new technologies in processing grapes, and branding.

Marketing activities are among the more important corporate strategies. Pavelková et al. (2009) emphasise that common marketing activities contribute to a common identity of the entities involved in the cluster, providing added value to the entire cluster and subsequently to all its actors. Concerning the competitive environment in the MVC area, it is interesting that over three quarters of subjects cooperate with their competitors on marketing activities (Fig. 11). The involvement in common marketing activities is higher among smaller business entities and micro-wine makers (totally and rather agree to the cooperation statement).

Customer satisfaction and positive references are clearly perceived as the most important forms of marketing in the MVC area (see Fig. 12). Although it is a rather individual form of marketing, it suggests that almost all the producers sensitively perceive the preferences of the (demanding) customers and reflect them, thus contributing to a good image of the wine industry throughout the region. Respondents also attribute great importance to participation in exhibitions, open door and open cellars days.

Business strategies are naturally differentiated by company size. Small businesses can sell all production because of good customer references. Large producers need to reach a wider range of potential customers, so they mainly focus on mass

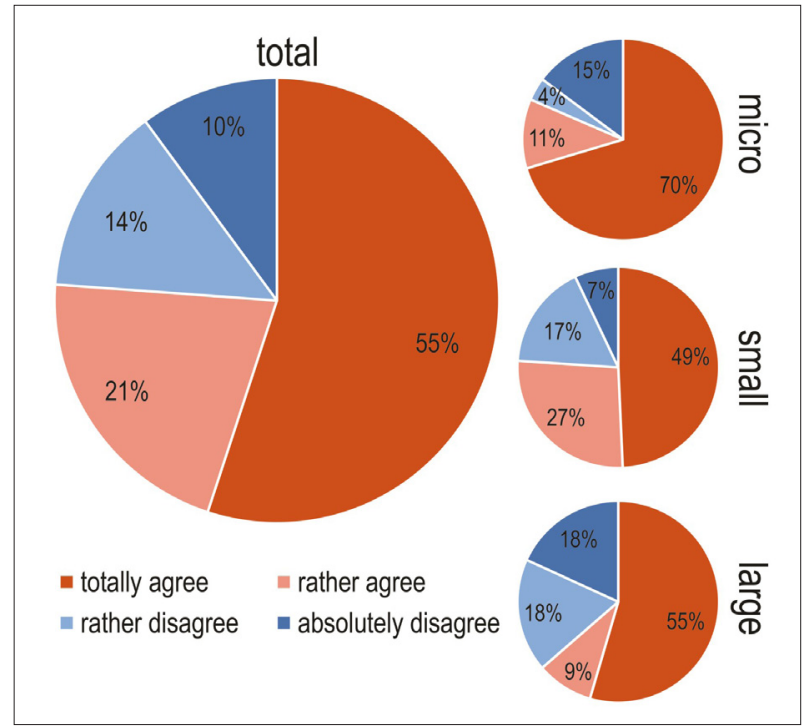

Fig. 11: Responses of the participants to the statement: We cooperate with our competitors on promotional activities. Source: authors' survey

marketing, particularly mass media (cf. Porter, 1998b). To certain extent, this is also the case in the MVC area, where customer satisfaction is important for all size categories of subjects, but media advertising is mainly used by larger enterprises (83.3\%).

Membership in a trade association contributes to a common identity for members, which can be considered as one of the highest levels of marketing (Stejskal, 2011). The wine organisations operating in the MVC region range from the local (a wine association in almost every LAU2), through regional and national and even to an international level 


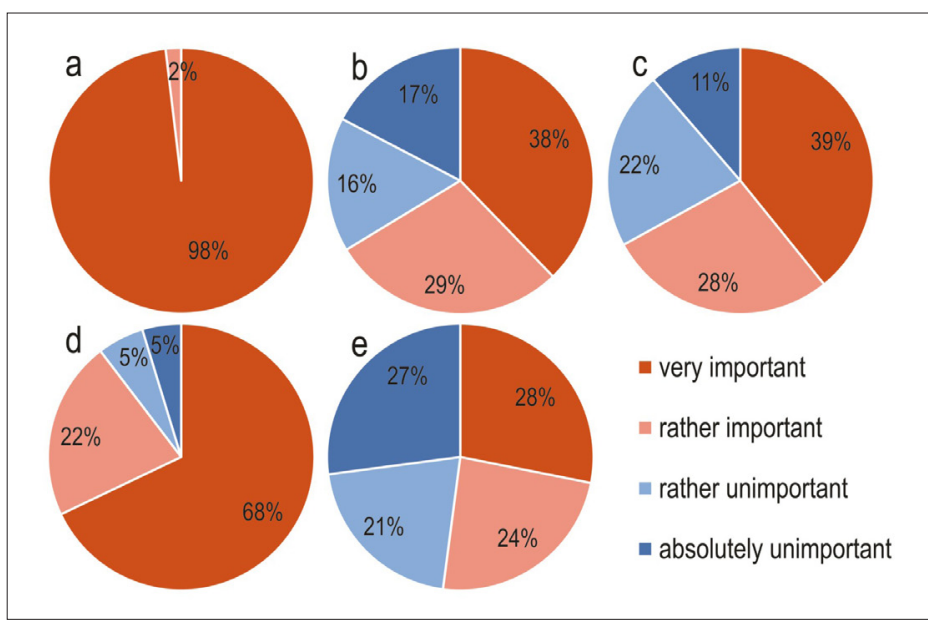

Fig. 12: Perceptions of the importance of chosen marketing forms: a) Customer satisfaction; b) Participation in exhibitions, open door and open cellars days; c) Membership in association; d) Web site; e) Advertising in media Source: authors' survey

(European Wine Knight Status). Almost all respondents declared membership in at least one association. Only $2.2 \%$ of business entities and 3.8\% micro-wine makers were not members of any such organisation. Almost all (95.6\%) of the respondents are members of the MVC association.

The wine associations organise exhibitions, competitions, tastings, wine tours and various social events, where wine makers have an opportunity to present themselves. Beside many other forms of marketing, membership in an association itself is important for almost two thirds of respondents. Over $91 \%$ of them expect the association to provide effective marketing and company presentation (see Fig. 13). Nevertheless, marketing is not the only motivation for membership in a wine association. It enables vine growers and wine makers to acquire new and important information and share experiences and good practices, as associations organise various professional trainings, schoolings or seminars (90\%). The motivation for membership in the association does not differ significantly among the various kinds of entities.

Almost nine in ten (86\%) respondents perceive memberships as an opportunity to gain new business contacts and as many as $75 \%$ to gain new and regular customers, pointing to the important role of an association in business networking in the region. Among other motivations, the respondents declared interests in an even higher number of promotional events, the opportunities to discuss problems, or to influence legislation. These responses identify the importance of associations in overcoming the barriers in competitiveness, which is the key attribute of an industrial cluster. The legal framework was most often (82.5\%) stated by respondents as a barrier to improving competitiveness (namely low subsidies, increased excise duty on wine, more profitable imports than domestic wine products), followed by the closely related problem of strong foreign competition in the form of cheap subsidised foreign wines (68.7\%).

\subsection{Related and supporting industries}

Since the relations between wine producers and customers were assessed in terms of the demand conditions, this section is focused on relations between producers and their suppliers. These linkages are among the most important features of an industrial cluster. A large number of specialised suppliers that are concentrated in a cluster territory is beneficial to producers as it results into lower entry costs, faster delivery, reduced inventory and subsequently general cost reductions (Pavelková et al., 2009).

The basic raw material for wine production is the grape. Only $11.1 \%$ of the wine producers get all of their grapes from external sources. On the other hand, $42.2 \%$ of winemakers process only grapes from their own vineyards. The remaining producers $(45.6 \%)$ use both their own grapes and supplies from other vine growers. This means that more than half of the wine makers establish cooperative ties with vine growers or other wine makers, who also grow vines to obtain grapes for their own wine production.

Although not as substantial as vine, other materials are also important for wine production and sale. In the survey, we analysed the spatial distribution of suppliers of chemicals, cork and plastic bottle stoppers, bottles, labels

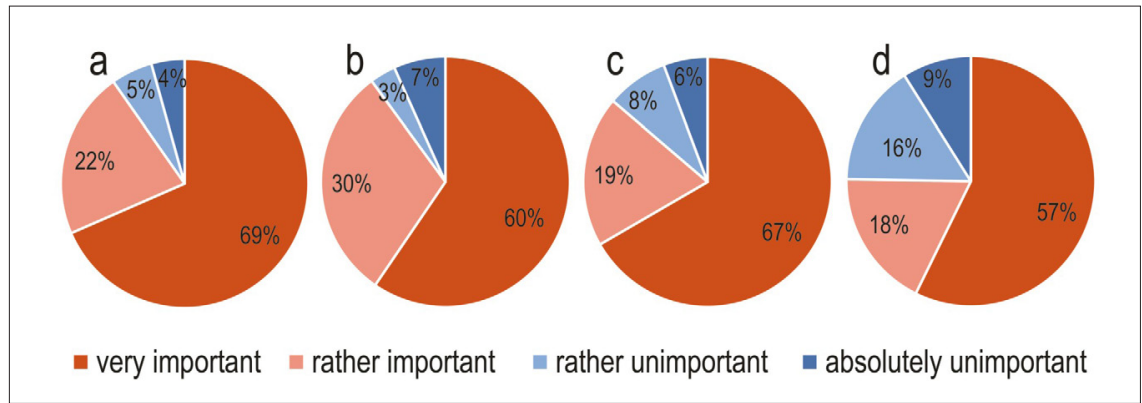

Fig. 13: The most important motivations for membership in a wine association: a) Effective marketing; b) Gaining up-to-date information; c) Establishing new contacts; d) New customers

Source: authors' survey 
and packaging. As shown in Fig. 14, the majority of supplies are bought from local or regional entities, and imports from other regions or from abroad are rather the exceptions.

Respondents were asked how they choose the supplier. Among the most important were quality of supplies (98.7\% of respondents) and adherence to delivery dates (91.9\%), followed by price, completeness of supplies (both above 85\%), and supplier references. The distance from supplier was the least frequently declared reason among all options (61.8\%). This finding indicates that a certain spatial concentration of supplier-customer relations in the region is not only the result of spatial proximity of suppliers, but rather one result of a competitive advantage based on regional specialisation in the wine industry.

\section{Discussion}

To identify the primary potential of industrial cluster emergence, we employed the localisation quotient, because it is among the most frequently used indicators of the spatial concentration of certain economic activities (cf. Griffith and Paelinck, 2018; Öztürk, 2009; Szymańska and ŚrodaMurawska, 2013; Žižka, 2010). Its value for beverages production in the MVC area is 1.52 , based on the data on employment of economically active persons. It importantly exceeds even the highest threshold values commonly used by scholars (Potomová and Letková, 2011). Regarding the structure of the beverage industry in the region, we assume that the result also indicates the concentration of the wine sector. This is confirmed by the high level of concentration of wine-producing business entities in the studied area.

Since the beginning of the $20^{\text {th }}$ century, the wine industry in Slovakia has suffered from several natural disasters and grapevine diseases (Malík, 2005), as well as social and economic transitions related to the establishment of the socialist centrally-planned economy and the post-socialist transformation (Hronský and Pintér, 2009; Popelková, 2016; Valúšková, 1998). During the post-socialist transformation, the region between Bratislava and Trnava recorded a rapid development of new industries and non-agricultural and non-industrial economic sectors (cf. Cerulíková et al., 2017). Despite these changes, analysis of the primary potential for industrial cluster emergence confirmed the increased concentration of the wine industry in the area of interest, hence the cluster potential. This shows strong relations of the wine industry with the physical geographic determinants of the area referred to as terroir (Ailer, 2010; Dominé, 2008), which persisted through substantial political and economic transitions. It also agrees with the Porter's (1990) idea that location in a specific environment is one of the key features of industrial clusters.

Several authors (e.g. Marshall, 1890; Nemcová, 2004; Rosenfeld, 2002) have emphasised the potential risks associated with the excessive orientation of a local economy to a single sector covered by a cluster. Geographic conditions in the MVC area and the well-developed and diversified economy of the wider region, however, are supposed to diminish the potential impact of a wine industry decline on the regional economy. The presence of a wine industry cluster should be beneficial for all of the involved actors and for the individual municipalities and the whole region. In brief, it does not make the regional economy dependent on the wine sector.

Locational advantage and the concentration of industry are necessary but not sufficient conditions for the emergence of a cluster as introduced by Porter (1990, 1998a, 1998b). Similarly, the establishment of a cluster initiative, which is represented by the MVC wine route association covering the entire area under observation, may stimulate but does not necessarily lead to the emergence of a natural industrial cluster. This is indicated also by Grabavčicová (2016), addressing the South Moravian region of the Czech Republic, where the vast majority of Czech wine production is concentrated, giving it the potential for cluster emergence. Attempts to establish a cluster initiative to support the cluster emergence (in 2005), however, failed due to the negative attitudes of the majority of potential actors. Such

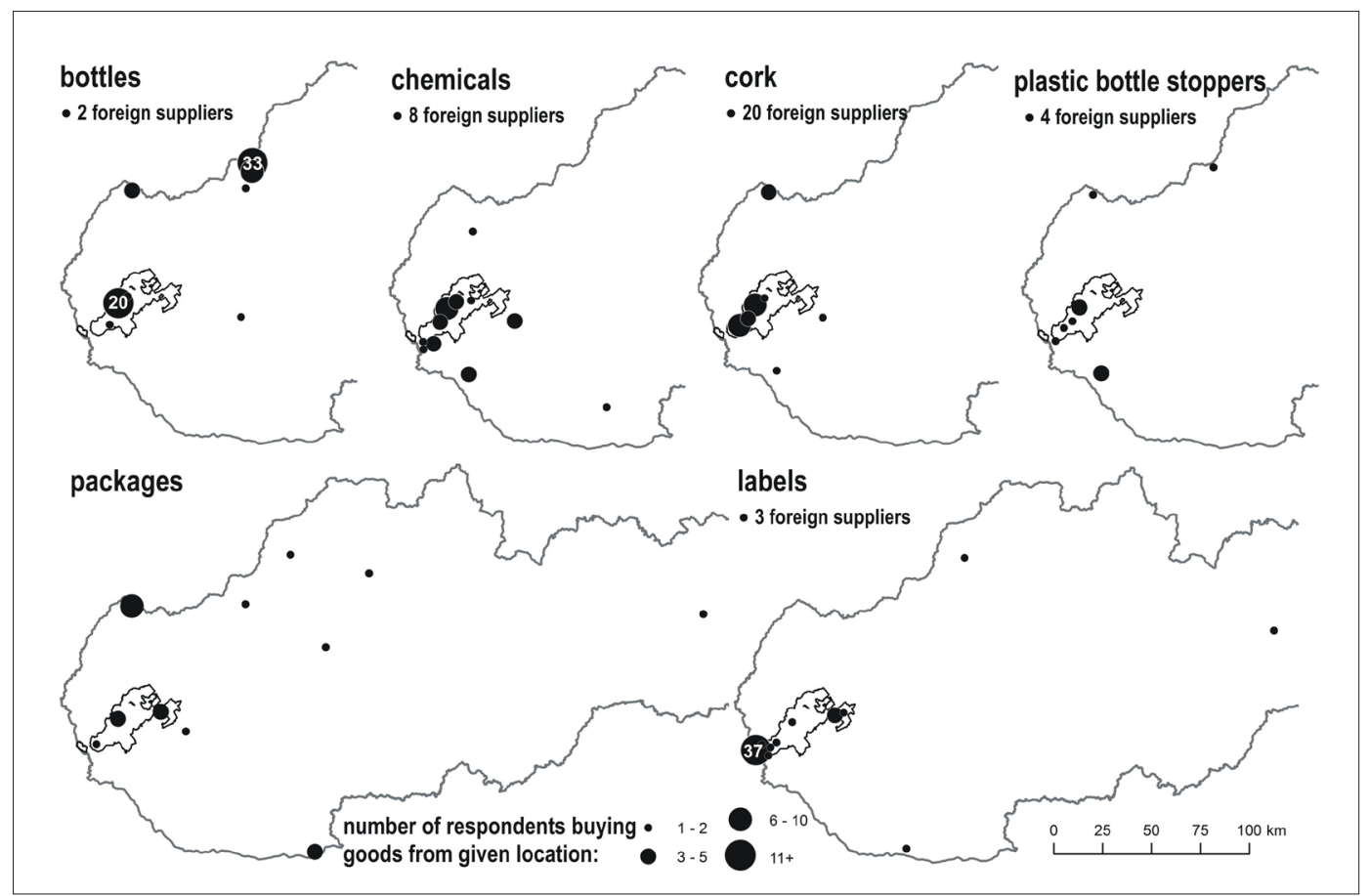

Fig. 14: Spatial distribution of suppliers of materials for wine production in the MVC region Source: authors' survey 
an industrial cluster has to provide competitive advantages to the involved actors, as well as to the whole industry in the cluster area. This advantage arises from a number of factors which Porter (1990) grouped and arranged into the scheme known as Porter's diamond. Based on this scheme, the interviews with wine makers operating in the MVC region were conducted to assess if the identified cluster potential was transformed into the existence of an actual industrial cluster. Such approach to cluster analysis is preferred by many scholars, e.g. Giuliani (2007), Huber (2012), Markusen (1996), Potter and Doug Watts (2011).

The identified linkages and relations among wine makers on the one hand and between wine makers and other entities on the other, take various forms. The supplierconsumer relations are very important, but cooperation in marketing or in educational activities is also significant for the existence of the cluster. The cooperation of wine producers and research and scientific institutions is very rare, however. The spatial range of these linkages is mainly regional. A wider spatial range of linkages has been identified in case of large wine producers.

Increasing the quality of production is being pursued by the majority of wine makers as a basis for competitiveness. Nevertheless, price is also perceived as an important instrument of competition. Competition and cooperation among individual entities in the MVC region stimulate innovations, and hence contributes to the competitiveness of the industry as a whole. These findings are largely consistent with the findings of Baptista and Swann (1998), Giuliani (2007) and Porter (1990) that involvement in the cluster tends to spur innovations. In this way it provides competitive advantage for the involved firms in comparison with isolated producers. While the majority of firms in the MVC region address innovation in wine quality, however, Bortoluzzi et al. (2015) indicate that the most successful firms in traditional Italian wine clusters are those with wide innovation scope (including marketing, business models), while narrow investments in improvement of products and production do not bring sufficient returns.

Competitive advantage for actors involved in the cluster arises also from other factors that are commonly perceived as industrial cluster features (e.g. Öztürk, 2009; Pavelková et al., 2009; Porter, 1990; Riddle, 2016). Among them, the producers highlight reduction of transaction costs for individual cluster members, and exploiting external economies of scale by sharing necessary information, knowledge of technologies and production inputs. This is closely related to easier and faster access to information, technologies and inputs. The particularly small entities with limited financial resources, appreciate the opportunity to increase their image and attract new customers by joint promotion and marketing activities, which they could barely perform as isolated entities.

The transfer of knowledge among business entities is among the important agglomeration effects in a cluster (Bortoluzzi et al. 2015; Markusen, 1996; Morrison and Rabellotti, 2009). This should also contribute to competitiveness by stimulating innovations (Pavelková et al., 2009). Such transfers take place by hiring employees with knowledge and experience from previous workplaces in the same industry. This was not identified in the MVC region, but the transfer of knowledge takes place because of meetings, discussions and workshops organised by local and regional associations, including the MVC association. There are also important informal meetings of vine growers and wine makers, which agrees with Bortoluzzi et al. (2015) who indicate that the most successful companies are these with more intimate relationships with other firms and institutions inside the cluster. Smaller wine makers highlight also an intergenerational transfer of knowledge in the MVC region.

Another agglomeration effect of a natural cluster (Markusen, 1996) is a specialised labour market. Although the majority of respondents consider qualified employees to be necessary for a successful business, they perceived the lack of such labour. This may be a reason for the low transfer of knowledge by employees, and about one half of respondents see it as an obstacle for increasing competitiveness. Such results indicate that the specialised labour market as described by Marshall (1890) was not developed in the MVC region. Nevertheless, it does not necessarily refute the existence of the cluster, but regarding other agglomeration effects and relations within the entities in the MVC region, it rather demonstrates that here is a cluster in the stage of growth as described by Potter and Doug Watts (2011). This idea is supported also by all kinds of proximity as defined by Boschma (2005) that were identified in the MVC region in the wine industry, namely cognitive, organisational, social, institutional and geographical effects. The MVC association then operates as a cluster initiative as defined by Lindqvist, Ketels and Sölvell (2013) and Sölvell, Lindqvist and Ketels (2003), contributing to the development of a natural industrial cluster.

\section{Conclusions}

The wine industry in the Malokarpatská vínna cesta (MVC) region was chosen as a case study based on the hypothesis that the strong dependence of the wine industry on specific geographical conditions could help this traditional wine region to overcome the effects of socialist industrialisation and the post-socialist transformations on the spatial distribution of economic activities in the CEECs.

The region of interest is located within the most developed part of Slovakia, in an economic sense. This region has recorded rapid economic development induced mainly by the automotive industry and non-industrial and non-agricultural sectors. Nevertheless, the concentration of the wine industry in the MVC region is still evident and it exceeds even the highest threshold values used by scholars to indicate the spatial concentration of an industry in a given area. These circumstances reveal the potential for industrial cluster formation and they confirm that location in a specific environment is one of the key features of an industrial cluster.

Further analysis demonstrates the mutual relations among wine makers in the region and other business entities and institutions. The concentration of wine makers and also suppliers and consumers, leads to a strong competition which stimulates innovations. Beside the competition, wide cooperation was identified among the wine industry entities within the region of interest. The cooperation is focused mainly on common marketing and educational activities. Thus both competition and cooperation boost the competitiveness of the individual wine makers and the wine industry in the MVC region.

The results confirm that the primary potential for an industrial cluster formation led to the development of a wine industry cluster in the MVC region. In comparison with established wine clusters in Western Europe and even 
South America, some aspects were not fully developed. This is particularly the case for a specialised labour market based on knowledge transfer by the inter-entity fluctuation of employees, and a relatively narrow focus on innovations to improve the quality of wine production. Such conditions result in neglecting investments in branding, marketing and export networks to sell product outside the region and abroad. It does indicate, however, that unlike mature Western European clusters, the case study MVC cluster is still in the stage of growth, and there is potential for the formation of a specialised labour market and shifts in the focus of investments in further stages of development. While the wine industry formed an industrial cluster as perceived by Porter (1990, 1998a, 1998b) in the MVC region, the MVC association acts as the cluster initiative that clearly contributed to the formation of the cluster.

These results provide important evidence on the formation of industrial clusters in post-socialist Central and Eastern European countries, contributing to the comprehensive research of wine clusters under various historical, political and economic conditions. Recognising the emergence of a wine industrial cluster is also a challenge for further indepth research. The focus should be on the identification of the specifics with respect to the clusters formed under capitalist conditions without a socialist past, and to more accurately assess the cluster's economic performance.

\section{Acknowledgement}

The research presented in this paper was financially supported by the Ministry of Education, Science, Research and Sport of the Slovak Republic under the grant VEGA 1/0395/17: Centripetal and centrifugal processes in the transformation of the regional system in Slovakia.

\section{References:}

AIASSA, P., BATLES, M., DANNER, S., FRISCHENGRUBER, H., HORVATH, R., KLOTZ, W. VACCA, A. (2018): Successful Wine Cooperatives: Field Reports from Cooperative Managers in Austria, Italy, and Germany. Journal of Wine Economics, 13(3): 243-259.

AIHU, W., GUIHUA, K. (2013): Research on the Evolution and Competition Situation of the Container Port Cluster System in China. In: Xiaowen, F. et al. [eds.]: Trade, Supply Chain Activities and Transport: Contemporary Logistics and Maritime Issues (pp. 445-452). Hong Kong, Hong Kong Polytechnic University.

AKUNDI, K. (2003): Cluster based Economic Development. Part1: A Survey of State Initiatives. Austin, Texas Economic Development, Business and Industry Data Center.

ALECKE, B., ALSLEBEN, C., SCHARR, F., UNTIEDT, G. (2008): Geographic concentration of sectors in the German economy: some unpleasant macroeconomic evidence for regional cluster policy. In: Maier, G., Blien, U. [eds.]: The Economics of Regional Clusters (pp. 209-233). Cheltenham, Edward Elgar.

AUDTRETSCH, D. B., FELDMAN, M. P. (1996): Innovative Clusters and the Industry Life Cycle. Review of Industrial Organization, 11(2): 253-273.

BAĎURÍK, J. (2005):Z dejín malokarpatského vinohradníctva a vinárstva. In: Malík. F. [ed.]: Víno Malých Karpát (pp. 445-452). Bratislava, Vydavatel'stvo PT.
BAPTISTA, R., SWANN, P. (1998): Do firms in clusters innovate more? Research Policy, 27(5): 525-540.

BERGMAN, E. M., FESER, E. J. (1999): Industrial and Regional Clusters: Concepts and Comparative Applications. The Web Book of Regional Science [online]. Morgantown, West Virginia University Regional Research Institute. Available at: http://www.rri.wvu.edu/ WebBook/Bergman-Feser/contents.htm

BLAŽEK, J., UHLÍŘ, D. (2011): Teorie regionálního rozvoje: nástin, kritika, implikace. Praha, Univerzita Karlova v Praze.

BORTOLUZZI, G., DE LUCA, P., VENIER, F., BALBONI, B. (2015): Innovation scope and the performance of the firm. Empirical evidence from an Italian wine cluster. In: Christiansen, B. [ed.]: Handbook of research on global business opportunities (pp. 551-568). Hershey, IGI Global.

BOSCHMA, R.A. (2005): Proximity and Innovation: A Critical Assessment. Regional Studies, 39(1): 61-74.

BRODZICKI, T., ROT, P., SZULTKA, S., TAMOWICZ, P., UMIŃSKI, S., WOJNICKA, E. (2002): Uwarunkowania rozwoju nowoczesnych technologii w Gdańsku. Gdansk, Instytut badań nad gospodarka rynkowa.

BRODZICKI, T., SZULTKA, S. (2002): Koncepcja klastrów a konkurencyjność przedsiębiorstw. Organizacja i kierowanie 110(4): 45-60.

CCTIA (2018): Winegrower areas and their segmentation from April $1^{\text {st }}, 2018$. Bratislava, CCTIA - The Central Control and Testing Institute in Agriculture [online]. [cit. 06.05.2018]. Available at: http://www.uksup.sk/ vinohradnicke-oblasti/

CECCATO, V., PERSSON, L. O. (2002). Dynamics of rural areas: an assessment of clusters of employment in Sweden. Journal of Rural Studies, 18(1): 49-63.

CORTRIGHT, J. (2006): Making Sense of Clusters: Regional Competitiveness and Economic Development. Washington, The Brookings Institution Metropolitan Policy Program.

CERULÍKOVÁ, A., DOČOLOMANSKÁ, E., HAASOVÁ, G., VACHOVÁ, A. (2017): Správa o hospodárskom vývoji v krajoch SR za rok 2016. Bratislava, Statistical Office of the Slovak Republic.

CUSMANO, L., MORRISON, A., RABELLOTTI, R. (2010): Catching up Trajectories in the Wine Sector: A Comparative Study of Chile, Italy, and South Africa. World Development, 38(11): 1588-1602.

DELGADO, M., PORTER, M. E., STERN, S. (2016): Defining clusters of related industries. Journal of Economic Geography, 16(1): 1-38.

DREWELLO, H., HELFER, M., BOUZAR, M. [eds.] (2016): Clusters as a Driving Power of the European Economy. Baden-Baden, Nomos.

DUMAN, P., BALOG, M., REHÁK, Š., ZAUŠKOVÁ, A., LOUČANOVÁ, E. (2009): Klastre na podporu rozvoja inovácií. Bratislava, Slovak Innovation and Energy Agency.

DUQUE, J. C., REY, S. J. (2008): A network based approach towards industrial clustering. In: Maier, G., Blien, U. [eds.]: The Economics of Regional Clusters (pp. 41-68) Cheltenham, Edward Elgar. 
DZIEMIANOWICZ, W., OLEJNICZAK, K. (2002): Cluster in Poland, the example of the printing cluster in Warsaw and recommendations on cluster support. Presentation from conference Cluster in Transition Economies: Motors for Growth and Social Innovation, Warsaw, April 22, 2002 [online]. [cit. 22.08.2018]. Available at: http://docplayer. pl/10965637-Analiza-klastrow-gospodarczych-wwojewodztwie-lubelskim.html

ELLISON， G., GLAESER, E. L. (1997): Geographic Concentration in U.S. Manufacturing Industries: A Dartboard Approach. Journal of Political Economy, 105(5): 889-927.

EZCURRA, R., GIL, C., PASCUAL, P. (2006): Regional specialization in the European Union. Regional Studies, 40(2): 601-616.

FESER, E. J. (2000): On the Ellison - Glaeser geographic concentration index. Working paper [online]. [cit. 16.09.2018]. Available at: http://www.urban.uiuc. edu/faculty/feser/Pubs/EG_index.pdf

GIULIANI, E. (2007): The selective nature of knowledge networks in clusters: evidence from the wine industry. Journal of Economic Geography, 7(2): 139-168.

GRABAVČICOVÁ, K. (2016): Zhodnocení potenciálu pro založení vinařského klastru vJihomoravském kraji. Diploma Thesis. Ostrava, Katedra regionální a environmentální ekonomiky, Ekonomická fakulta, VŠB-TU.

GREGORY, D., JOHNSTON, R., PRATT, G., WATTS, M., WHATMORE, S. (2009): The Dictionary of Human Geography. Chichester, Blackwell Publishing.

GRIFFITH, D. A., PAELINCK, J. H. P. (2018): Morphisms for Quantitative Spatial Analysis. Cham, Springer.

HALUZA, I. (2018): Vína vyššej kvality bude môct vyrábat d’alších 199 slovenských obcí. eTrend.sk [online]. [cit. 11.10.2018]. Available at: https://www.etrend.sk/ podnikanie/vina-vyssej-kvality-bude-moct-vyrabatdalsich-200-slovenskych-obci.html

HANUŠIN, J., OŤAHEL', J. (2013): Cultural Landscape of the Sub-Little Carpathian Region: Geoecological and Cultural-historical Memory - Problems, Preservation and Development. Geographia Cassoviensis, 7(2): 13-21.

HANUŠIN, J., ŠTEFUNKOVÁ, D. (2015): Changes in vine-growing landscape diversity in the hinterland of Svätý Jur town in 1896-2011. Geografický časopis, 67(3): 243-259.

HOFE, R., CHEN, K. (2006): Whither or not industrial cluster: conclusions or confusions? The Industrial Geographer, 4(1): 2-28.

HERVAS-OLIVER, J. L., LLEO, M., CERVELLO, R. (2017): The dynamics of cluster entrepreneurship: Knowledge legacy from parents or agglomeration effects? The case of the Castellon ceramic tile district. Research Policy, 46(1): 73-92.

HRONSKÝ, Š., PINTÉR, E. (2009): Situation of vocational training and education systems in viniculture area [online]. [cit. 19.03.2018]. Available at: http://svapezinok. sk/files/gallery/20091015134800_Odborne\%20 vzdelavanie\%20v\%20SR_SK.pdf

HUBER, F. (2011). Do clusters really matter for innovation practices in Information Technology? Questioning the significance of technological knowledge spillovers. Journal of Economic Geography, 12(1): 107-126.

KARLÍK, L., GÁBOR, M., FALŤAN, V., LAUKO, V. (2017): Monitoring of vineyards utilization: case study Modra (Slovakia). Geographia Cassoviensis, 11(1): 22-32.

KAŹMIERSKI, J. (2011): Klastry jako źródło efektów synergetycznych $\mathrm{i}$ instrument zarządzania regionalnego. Acta Universitatis Lodziensis Folia Oeconomica, 251: 27-38.

KAZIMÍR, Š. (1986): Pestovanie viniča a produkcia vína na Slovensku v minulosti. Bratislava, Veda vydavatel'stvo Slovenskej akadémie vied.

KETELS, C., LINDQVIST, G., SÖLVELL, Ö. [eds.] (2006): Cluster Initiatives in Developing and Transition Economies. Stockholm, Center for Strategy and Competitiveness.

KETELS, C., SÖLVELL, Ö. (2006): Clusters in the EU-10 New Member Countries. Presentation for Europe Inova Cluster Mapping, Valencia, Spain, November $27^{\text {th }}, 2006$ [online]. [cit. 20.03.2018]. Available at: https://www.hhs. se/contentassets/f5af04d2a71a470289b4151bd5a1f5c3/ eu-10-report-valencia-11-27-06-ck.pdf

KOWALSKI, A. M. (2016): Territorial location of ICT cluster initiatives and ICT-related sectors in Poland. In: Drewello, H., Helfer, M., Bouzar, M. [eds.]: Clusters as a Driving Power of the European Economy (pp. 48-65). Baden-Baden, Nomos.

KOWALSKI, A. M., MARCINKOWSKI, A. (2012): Clusters versus Cluster Initiatives, with Focus on the ICT Sector in Poland. European Planning Studies, 22(1): 20-45.

KULLA, M. (2010): Transformácia priemyslu Slovenska po roku 1989 [online]. In: Mezei, I. et al. [eds.]: Geografické poznatky bez hraníc. Košice, Pavol Jozef Šafárik University. Available at: https://www.upjs.sk/public/ media/3467/Geograficke-poznatky-bez-hranic.pdf

LINDQVIST, G., KETELS, C., SÖLVELL, Ö. (2013): The Cluster Initiative Greenbook 2.0. Stockholm, Ivory Tower Publishers.

MALÍK, F. [ed.] (2005): Víno Malých Karpát. Bratislava, Vydavatel'stvo PT.

MÁRIÁSSYOVÁ, A., GURŇÁK, D. (2016): Analysis of housing stock as one of the factors of town identity (case study of the town Modra). Geographia Cassoviensis, 10(1): 18-28.

MARKOVÁ, B. (2014): Creative clusters in the Czech Republic - strategy for local development or fashionable concept? Moravian Geographical Reports, 22(1): 44-50.

MARKUSEN, A. (1996). Sticky Places in Slippery Space: A Typology of Industrial Districts. Economic Geography, 72(3): 293-313.

MARELLI, E. (2007): Specialisation and Convergence of European Regions. The European Journal of Comparative Economics, 4(2): 149-178.

MARSHALL, A. (1890): Principles of Economics [online]. London, Macmillan. Available at: http://oll.libertyfund. org/titles/marshall-principles-of-economics- $8^{\text {th }}$-ed

MARTIN, R., SUNLEY, P. (2003): Deconstructing clusters: chaotic concept or policy panacea? Journal of Economic Geography, 3(1): 5-35. 
MISR (2013): Trade Register of the Slovak Republic [online]. Bratislava, MISR - Ministry of Interior of the Slovak Republic [cit. 19.01.2013]. Available at: https://www.zrsr. sk/default.aspx?LANG =en

MJSR (2013): Business Register of the Slovak Republic [online]. Bratislava, MJSR - Ministry of Justice of the Slovak Republic [cit. 22.01.2013]. Available at: http:// www.orsr.sk/Default.asp?lan=en

MLÁDEK, J. (1990): Teritoriálne priemyselné útvary Slovenska. Bratislava, Univerzita Komenského.

MÖLLER, J., LITZEL, N. (2008): Measuring specialisation and concentration in regional clusters - an empirical analysis for Eastern Bavaria. In: Maier, G., Blien, U. [eds.]: The Economics of Regional Clusters (pp. 119144.). Cheltenham, Edward Elgar.

MORRISON, A., RABELLOTTI, R. (2009): Knowledge and Information Networks in an Italian Wine Cluster. European Planning Studies, 17(7): 983-1006.

NCSR (2009): Decree No. 350/2009 Coll., which implements certain provisions of Act no. 313/2009 Coll. on vinegrowing and wine-making. Bratislava, NCSR - National Council of the Slovak Republic.

NEMCOVÁ, E. (2004): Klastre a ich úloha v rozvoji regiónu. Ekonomický časopis, 52(6): 739-754.

OORT, F. G., BURGER, M. J., RASPE, O. (2008): Inter-firm relations and economic clustering in the Dutch Randstad region. In: Maier, G., Blien, U. [eds.]: The Economics of Regional Clusters (pp. 41-68). Cheltenham, Edward Elgar.

ÖZTÜRK, H. E. (2009): The role of cluster types and firm size in designing the level of network relations: The experience of the Antalya tourism region. Tourism Management, 30(4): 589-597.

PAVELKOVÁ, D. et al. [eds.] (2009): Klastry a jejich vliv na výkonnost firem. Praha, GRADA Publishing.

POPELKOVÁ, K. (2016): Malokarpatské vinobranie v 70. rokoch 20. storočia - socialistický sviatok kolektivizovaného pol'nohospodárstva. Forum Historiae, 10(1): 107-117.

POPOVČIĆ AVRIĆ, S., BRKIĆ, I., ŠESTOVIĆ, M. (2016): Clusters as a development factor in the south-east Europe (SEE) countries. In: Drewello, H., Helfer, M., Bouzar, M. [eds.]: Clusters as a Driving Power of the European Economy (pp. 198-211). Baden-Baden, Nomos.

PORTER, M.E. (1990): The Competitive Advantage of Nations. Harvard Business Review, 68(2): 71-91.

PORTER, M. E. (1998a): Clusters and the New Economics of Competition. Harvard Business Review, 76(6): 77-90.

PORTER,M. E. (1998b):ClustersandCompetition:NewAgendas for Companies, Governments, and Institutions. Harvard Business School Working Paper [online]. [cit. 17.08.2018]. Available at: http://citeseerx.ist.psu.edu/viewdoc/ download?doi=10.1.1.199.4104\&rep=rep1\&type $=$ pdf

PORTER, M. E. (2000): Location, Competition, and Economic Development: Local Clusters in a Global Economy. Economic Development Quarterly, 14(1): 15-34.

POTOMOVÁ, J., LETKOVÁ, J. (2011): Problémy identifikácie potenciálnych odvetví vhodných pre vznik a rozvoj klastra. Acta Geographica Universitatis Comenianae, 55(1): 93-113.
POTTER, A., DOUG WATTS, H. (2011): Evolutionary agglomeration theory: increasing returns, diminishing returns, and the industry life cycle. Journal of Economic Geography, 11(3): 417-455.

RIDDLE, P. (2016): Location and Company Competitive Advantage: The View from the Business. In: Full Papers - RSA Annual Conference Graz 2016 [online]. Regional Studies Association. Available at: https://www. regionalstudies.org/presentations/rsagraz2016-fullpapers/

ROSENFELD, S. A. (2002): Creating Smart systems. A guide to cluster strategies in less favoured regions. European Union - Regional Innovation Strategies. Carrboro, Regional Technology Strategies.

ROVNÝ, P., DOBÁK, D., NAGYOVÁ, L. (2010): Dopad spoločnej pol'nohospodárskej reformy EÚ vo vinárskom sektore na pestovatel'ov viniča v SR. In: III. Medzinárodné vinohradnícke a vinárske fórum, Trenčianske Teplice 17.-19. februára 2010. Nitra, SPU.

RUFFONI, J., TATSCH, A. L., STEFANI, R., SCHAEFFER, P. R., GRINGS, L. G. (2017): Does the Geographical Proximity Matter in Knowledge and Information Flow? A study about wine cluster in the Southern region of Brazil. Revista de Economia e Sociologia Rural, 55(3): 569-588.

SAMBIDI, P. (2008): Regional Industry Cluster Analysis for the Gulf Coast Economic Development District. Houston, Department of Community and Environmental Planning.

SIMMIE, J. (2004): Innovation and Clustering in the Globalised International Economy. Urban Studies, 41(5/6): 1095-1112.

SKOKAN, K. (2002a): Industry Clusters v regionálním rozvoji. Ekonomická revue, 5(2): 50-60.

SKOKAN. K. (2002b): Industry Clusters - odvětvová seskupení firem v rozvoji moravskoslezského kraje. In: Viturka, M., Vystoupil, J. [eds.]: V. mezinárodní kolokvium o regionálních vědách: Sborník příspěvků z kolokvia, 26.-28.6.2002 (pp. 145-162). Brno, Masarykova univerzita.

SKOKAN, K. (2008): Role klastrů v regionálním rozvoji. In: Wokoun, R. et al. [eds.]: Regionální rozvoj: východiska regionálního rozvoje, regionální politika, teorie, strategie a programování (pp. 287-303). Praha, Linde.

SOSR (2011): Results of the population census 2011 [online]. Bratislava, SOSR - Statistical Office of the Slovak Republic. Available at: https://census2011.statistics.sk/ tabulky.html

SOSR (2012): Statistical register of organizations [online]. Bratislava, SOSR-Statistical Office of the Slovak Republic [cit. 17.01.2013]. Available at: https://slovak.statistics.sk/ wps/portal/ext/Databases/register_organizacii/

SÖLVELL, Ö, LINDQVIST, G., KETELS, C. (2003): The Cluster Initiative Greenbook. Stockholm, Ivory Tower AB.

SOVIAR, J. (2009): Cluster Initiatives in Žilina Region (Slovak Republic). Economics and Management, 14: 528-534.

STEJSKAL, J. (2009). Competitiveness advantage analysis as one method for cluster identification. In: $3^{\text {rd }}$ Central European Conference in Regional Science - International Conference Proceedings (pp. 1337-1346). Košice, Technical University, Faculty of Economics. 
STEJSKAL, J. (2011): Analysis of the applicability of selected methods for industrial clusters identifying. International Journal of Systems Applications, Engineering and Development, 3(5): 255-262.

STEJSKAL, J., HÁJEK, P. (2009): The Notes to Methods for Industrial Cluster Identification. Scientific Papers of the University of Pardubice, 14: 232-240.

STEJSKAL, J., HÁJEK, P. (2012): Competitive advantage analysis: A novel method for industrial clusters identification. Journal of Business Economics and Management, 13(2): 344-365.

SZÉKELY, V. (2008): Regionálne priemyselné klastre a problémy (nielen) s ich identifikáciou. Ekonomický časopis, 56(3): 233-238.

SZULTKA, S., WOJNICKA, E. (2003): Skupiska działalności inwestycyjnej w Polsce. Przypadek przedsiębiorstw automatyki przemysłowej w regionie gdańskim. Ekonomista 2015(4): 521-538.

SZYMAŃSKA, D., ŚRODA-MURAWSKA, S. (2013): The concentration of the creative sector firms as a potential basis for the formation of creative clusters in Poland. Bulletin of Geography. Socio-economic Series, 20: 85-93.

THOMAS, L. C., PAINBÉNI, S., BARTON, H. (2013): Entrepreneurial marketing within the French wine industry. International Journal of Entrepreneurial Behaviour \& Research, 19(2): 238-260.

TRIPPL, M. (2004): Innovative Cluster in alten Industriegebieten. Wien, LIT Verlag.
TT-LIVE (2015): V Trnave máme svetovú firmu - Lycos! [online]. Trnava, Portál Trnava-live.sk. Available at: http://www.trnava-live.sk/2015/11/25/v-trnave-mamesvetovu-firmu-lycos/

TURINA, M., CONFESSORE, G., BARBANTE, I., BUZZI, O., TURINA, S. (2016): Hub agribusiness in the Center Italy: Simulation of the growth of a new "industrial cluster" through logistic functions. Agriculture and Agricultural Science Procedia 8: 353-371.

VALÚŠKOVÁ, Z. (1998): Vinohradníctvo Slovenska s užším pohladom na Malé Karpaty. Diploma thesis. Bratislava, Faculty of Natural Sciences, Comenius University.

WILSON, P. (2016): The Impact of Culture on Cluster Competitiveness: a Revised Diamond Model. In: Drewello, H., Helfer, M., Bouzar, M. [eds.]: Clusters as a Driving Power of the European Economy (pp. 162-175). Baden-Baden, Nomos.

ZEN, A. U., FENSTERSEIFER, J. E., PRÉVOT, F. (2011): Internationalisation of Clustered Companies and the Influence of Resources: A Case Study on Wine Clusters in Brazil and France. Latin American Business Review, 12(1): 123-141.

ŽIŽKA, M. (2010): Quantitative methods of identification of industry clusters. In: Mathematical Methods in Economics $2010-28^{\text {th }}$ International Conference, 8.-10. September 2010 (pp. 700-705). České Budějovice, Jihočeská univerzita, Ekonomická fakulta.

\section{Please cite this article as:}

NOVOTNÁ, J., NOVOTNÝ, L. (2019): Industrial clusters in a post-socialist country: The case of the wine industry in Slovakia. Moravian Geographical Reports, 27(2): 62-78. Doi: 10.2478/mgr-2019-0006. 